\title{
Modeling and Risk Analysis of Dam-Break Flooding in a Semi-Arid Montane Watershed.
}

\author{
Aissam Gaagai ${ }^{1}$, Hani Amir Aouissi 1,* , Andrey E. Krauklis ${ }^{2}$, Juris Burlakovs ${ }^{3}$, Ali Athamena ${ }^{4}$, Ivar Zekker ${ }^{5}$, Ab- \\ derrahmane Boudoukha ${ }^{6}$, Lahcen Benaabidat ${ }^{7}$ and Haroun Chenchouni ${ }^{8,9}$
}

1 Scientific and Technical Research Center on Arid Regions (CRSTRA), 07000 Biskra, Algeria; gaagaiaissam37@gmail.com (G.A); aouissi.amir@gmail.com (H.A.A).

2 Institute for Mechanics of Materials, University of Latvia, Jelgavas Street 3, LV-1004 Riga, Latvia; andykrauklis@gmail.com (A.E.K).

3 Rural Building and Water Management, Estonian University of Life Sciences, Kreutzwaldi 5, 51014 Tartu, Estonia; Juris.Burlakovs@emu.ee (J.B).

4 Department of Geology. Institute of Earth and Universe Sciences. University of Batna 2, 05078 Fesdis, Algeria; a.athamena@univ-batna2.dz (A.A).

5 Institute of Chemistry, University of Tartu, 14a Ravila St., 50411 Tartu, Estonia; ivar.zekker@ut.ee (I.Z).

6 Laboratoire de Recherche Appliquée en Hydraulique, University of Batna 2, 05078 Fesdis, Algeria; boudoukha_abderrahmane@yahoo.fr (A.B).

7 Laboratory of Functional Ecology and Environment Engineering, University of Sidi Mohammed Ben Abdellah, 30500 Fez, Morocco; benaabidate@gmail.com (L.B).

8 Department of Nature and Life Sciences, Faculty of Exact Sciences and Nature and Life Sciences, University of Tebessa, 12002 Tebessa, Algeria.

9 Laboratory of Natural Resources and Management of Sensitive Environments 'RNAMS', University of Oum-El-Bouaghi, 04000 Oum-El-Bouaghi, Algeria; chenchouni@gmail.com (H.C).

* Correspondance: aouissi.amir@gmail.com; +213662387144

\begin{abstract}
The risk related to embankment dam breaches needs to be evaluated in order to prepare emergency action plans. The physical and hydrodynamic parameters of the flood wave generated from dam-failure event correspond to various breach parameters such as width, slope and formation time. This study aimed to simulate dam-breach failure scenario of Yabous dam (NE Algeria) and analyze its influence on areas (urban and natural environments) downstream the dam. The simulation was completed using the sensitivity analysis method in order to assess the impact of breach parameters on the dam-break scenario. The propagation of flood wave associated to dam-break was simulated using the one-dimensional HEC-RAS hydraulic model. This study applied a sensitivity analysis of three breach parameters (slope, width, and formation time) in five sites selected downstream the embankment dam. The simulation showed that the maximum flow of the flood wave recorded at the level of the breach was $8768 \mathrm{~m} 3 / \mathrm{s}$, which gradually attenuated along the river course to reach $1579.2 \mathrm{~m} 3 / \mathrm{s}$ at about $8.5 \mathrm{~km}$ downstream the dam. This study established the map of flood-prone areas that illustrated zones threatened with the flooding wave triggered by the dam failure due to extreme rainfall events. The sensitivity analysis showed that flood wave flow, height and width revealed positive and similar changes for the increase in adjustments $( \pm 25 \%$ and $\pm 50 \%$ ) of breach width and slope in the 5 sites. However, flood wave parameters of breach formation time showed significant trends that changed in the opposite direction compared to breach slope and width.
\end{abstract}

Keywords: Dam breach parameters; dam failure scenario; flood hazard; flood hydrodynamics; flood simulation; simulated natural hazard.

\section{Introduction}

Dam-failure floods are one of the most serious environmental disasters, which result in irreversible ecological, social and economic consequences. Previous studies assessing dam failure risk revealed that breaching risk and dam failure process can be predicted based on the past dam failure events [1-4]. The reports which describe dam-breaks 
causing casualties around the world are multiple, for example (1) the Marib dam (Yemen) in 575, (2) an earthen dam near Grenoble (France) in 1219, (3) in 1923, 1935 and 1985, three dam failure cases in Italy caused the loss of many human lives in Gleno, Molare and Stava, respectively [5]. In Algeria, a dam called 'Fergoug I' killed approximately 200 individuals in 1881 in the region of Mascara [6].

In a constantly changing world, dam failure due to climate change is considered as a worldwide escalating phenomenon. Usually in studies of dams, the dam body (height, width and slope for earthen dams) including the ancillary structures are dimensioned conforming to the flood hydrograph. According to recent climate changes, the flood hydrograph recorded at many dams is following an ascending curve compared to previous years [7]. This, therefore, can influence the body of the dam and even the structures. For example, if the spillway does not support all the flood input, this flood will systematically discharge on the dam crest to create a breach on the dike. The breach can cause a partial or a total failure of the structure, depending on the resistance of the dam body. Therefore, the impact of climate change on dams is reported as one of the major problems that require rigorous and permanent monitoring of dams with assessment of flooding hazard risk [8,9]. In this sense, in 2015 during the construction of Yabous dam, built upstream the city of Yabous (a mountain area near the province of Khenchela, NE Algeria), an exceptional flood was recorded after heavy rains, which hit this region. The first author (AG) was a hydrology engineer monitoring the construction project during that period. He clearly observed the destructive effects of this flood on all the structures, in particular the discharge of the flood on the sails of the spillway dissipation basin.

Consequently, a comprehensive management plan of flood plains and watersheds using acute scientific knowledge can reduce flood damages, thus, the prevent socioeconomic losses and the environmental degradation [10-12]. Actually, most dam failures and flooding events resulted from mismanagement practices and/or outdated plans that did not consider or project extreme meteorological events under climate change scenarios-exceeding dam dimensioning and reservoir capacity [13,14]. Although the methods investigating flood mitigation are numerous and diverse, flood mitigation remains difficult to fully address because flooding is a complex phenomenon that involves several changing and unpredictable variables [8]. In order to reduce risks of floods caused by dam failure, scientists as well as decision-makers should consider all natural and anthropogenic factors that can predict the risk. In addition, the procedure of studying dam failure must include the delimitation of the risk zone downstream the dam and investigate also all breach formation parameters that may influence this scenario using sensitivity analysis methods in order to accurately validate simulation modeling outputs [15]. For instance, failure mode, dynamic failure geometry, flow conditions, breach progression, time, materials and dam type can affect the estimation of the propagation wave resulting from a dam failure. In this regard, previous studies applying the sensitivity analysis highlighted that the above-mentioned parameters have various influences on the peak flow in terms of dam geographic location, flood magnitude, etc. [16,17]. In fact, case studies and/or modeling approaches are generally used to predict the parameters of dam failure, where sensitivity analysis is an important aspect in the use of hydraulic models. The application of sensitivity analysis is essential in decision-making processes to ensure consistency of the final decision [18]. Through the sensitivity analysis, different simulation scenarios could be visualized, which is useful for observing the impact of the parameters changing towards the final alternative ranking. The sensitivity analysis allows to observe how the final assessment is likely to change, and it also measures the change magnitude generated by a certain extent of the weight differences in the predicted parameters $[19,20]$.

For assessing floods caused by dam failures, several studies have applied analytical models including one-dimensional (MIKE11 and HEC-RAS 1D) and two-dimensional 
models (FLDWAV, DELFT-FSL, TELEMAC 2D, MIKE2, HEC-RAS 2D). While all these models are designed to probe and solve the same issue, their principle is not the same. For example, the models MIKE11 and HEC-RAS require the geometrical characteristics of the land, which allows drawing cross and perpendicular sections of flow direction and then determining water height and flowing velocity in each point along the river [21-24]. Moreover, the FLDWAV, DELFT-FSL, TELEMAC 2D, MIKE2, HEC-RAS 2D models require a digital elevation model (DEM), which ensures a continuous aspect of land topography [25]. Gee et al. [26] compared aspects of dam failure using two two-dimensional models (HEC-RAS 2D and FLDWAV) and concluded that the difference in the geometry of the river is the main driver of simulation differences between the two models. In recent years, the simulation of propagation of flood waves in open channels downstream the dams in failure events was further improved with the development of high DEM quality and cutting-edge tools of geographic information systems (GIS) [27]. Recent studies on flood inundation modeling are involving the application of combined methods including statistical modeling techniques, remote sensing and GIS tools $[28,29,7]$.

This study aimed to analyze dam failure scenario and determine its influence in urban area downstream the dam in a semi-arid region in northeast Algeria (Yabous, Khenchela). This simulation highlights, using the sensitivity analysis, the impact of breach parameters on the dam failure scenario in several sites selected downstream the dam including different structures i.e. mainly inhabited urban areas, the axis of the dam itself, bridges, etc. In addition, this study aimed at achieving a comprehensive modeling of the dam failure process and its consequences using a mixture of datasets (geomatics, hydrological and hydraulic data) with the application of one-dimensional Hydrologic Engineering Centers-River Analysis System "HEC-RAS" model. Using the sensitivity analysis, the study investigated how flood simulation reliabilities are influenced by different sources of input data. The purposely chosen analysis was carried out by gradually changing the values of each breach parameter in order to observe the ranking order resulting from these changes. The study is also aiming at the characterization of physical and hydrodynamic parameters of simulated flood wave at different zones located at high flood risk downstream the dam and along the Yabous river in order to assess the impact of dam-break flood.

\section{Materials and Methods}

\subsection{Study Area and Dam Characteristics}

\subsubsection{Geographic Location and Dam Characteristics}

The Yabous dam $\left(35^{\circ} 23^{\prime} 34.5^{\prime \prime} \mathrm{N}, 06^{\circ} 38^{\prime} 45.8^{\prime \prime} \mathrm{E}\right.$, elevation=1222.2 $\mathrm{m}$ a.s.l.) is located 63 $\mathrm{km}$ west of Khenchela City at the Northern foothills of Jebel Chélia (Figure 1). The climate of the region is semi-arid with annual precipitation varied between 350 and $400 \mathrm{~mm}$ and evapotranspiration exceeded rainfall due to frequent and long drought episodes, which result in no aquifer recharge [30]. The landscapes of the region include montane woodlands, shruby mountains and high plains used in rainfed cereal crops [31]. 


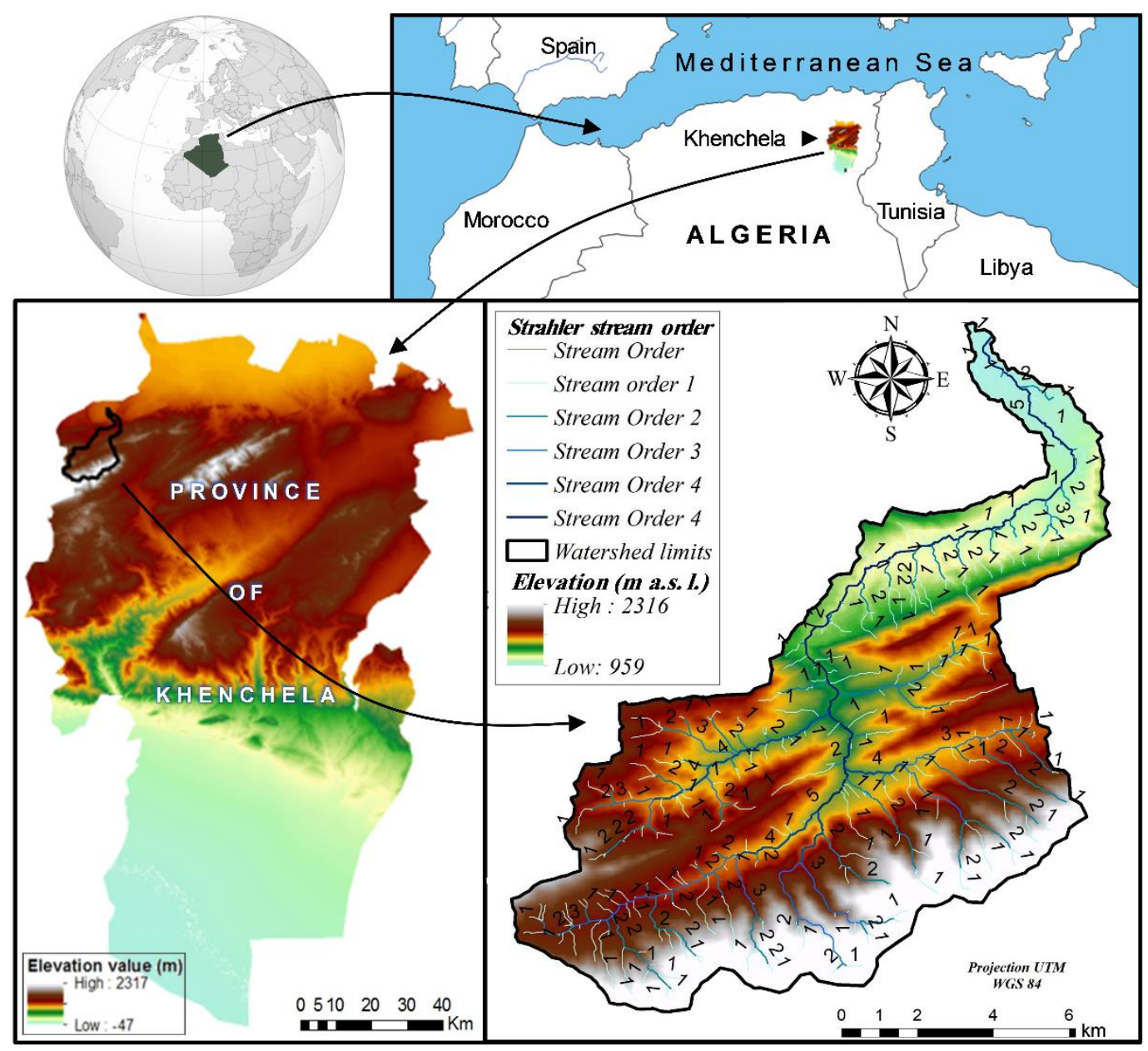

Figure 1. Geographic location and elevation maps of the study area "Yabous watershed" located western the Province of Khenchela (bottom left map) in northeastern Algeria. The map of Yabous watershed (bottom right) includes the hydrographic network with Strahler stream orders.

Immediately at about $2 \mathrm{~km}$ downstream the dam, the village of Yabous $(\sim 12,000$ inhabitants) is located with a position stretching for $2 \mathrm{~km}$ next to the Yabous river on which the dam was constructed (Figure 2). The position of Yabous town toward the dam represents a real risk to the population in different ways (environmental, social and economic) especially the infrastructure; knowing that the road \# N45 stretches for more than $8 \mathrm{~km}$ alongside Yabous river. Actually, the locals became very concerned about the hazard that presents the dam in case of failure, which urged the authorities to create an effective alarm system on the downstream zones prone to flooding associated to dam-rupture events.

Technically, the dam was built of earth with a clay core, dam height $=43 \mathrm{~m}$, span=460 $\mathrm{m}$, crest width $=10 \mathrm{~m}$. Its storage capacity $\approx 7.5$ million $\mathrm{m} 3$ and the volume exploited $\approx 5.7$ million $\mathrm{m} 3$ of water. Dam water is not yet exploited, but it is projected to supply 33,000 inhabitants of surrounding regions with drinking water $(\sim 1$ million $\mathrm{m} 3$, with daily allocation of $4,800 \mathrm{~m} 3)$ and irrigation water ( 2 million $\mathrm{m} 3)$ destined to agricultural lands (>500 ha) of mainly apple orchards. 


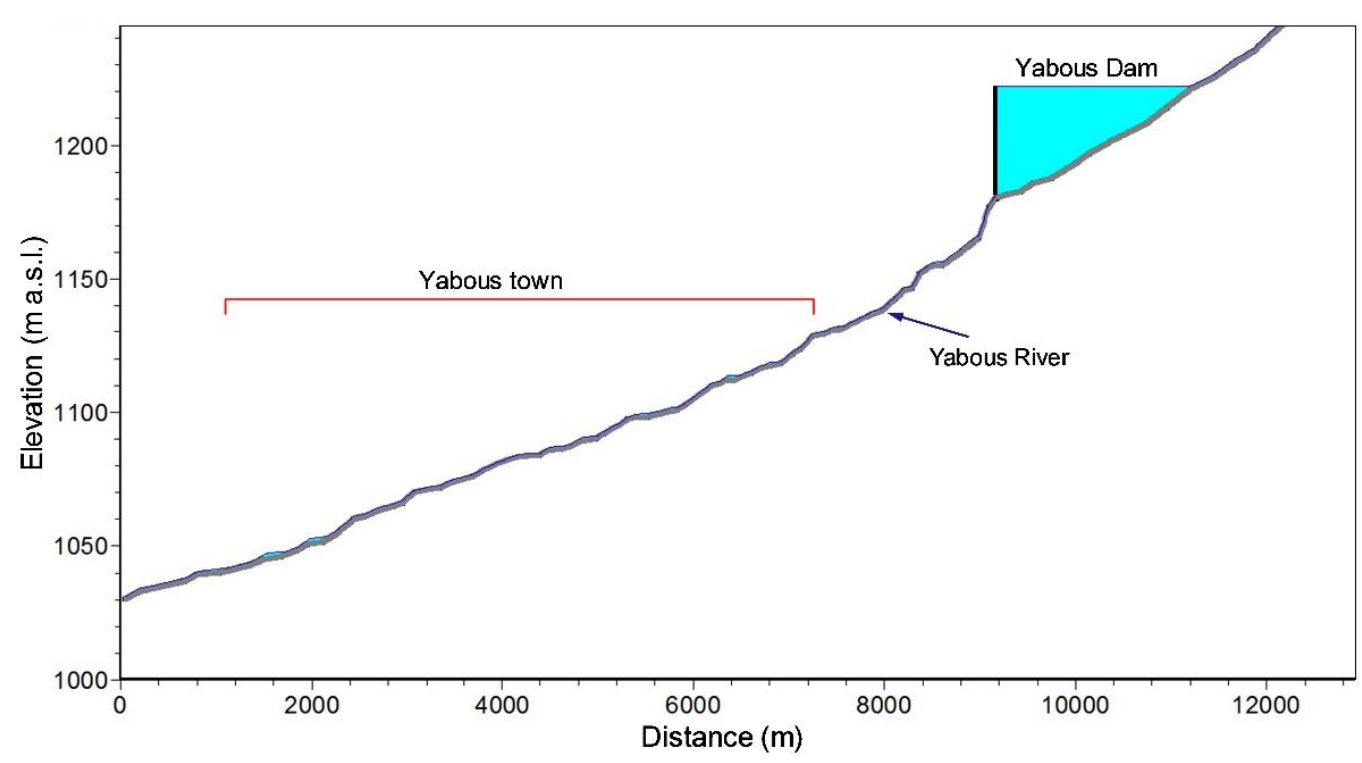

Figure 2. Longitudinal profile of Yabous river and town located downstream of dam reservoir.

\subsection{Data Collection, Processing and Modeling Approach}

\subsubsection{Data Processing}

The satellite image of the study area was retrieved from the ASTER (Advanced Space borne Thermal Emission and Reflection Radiometer) satellite at 30-m spatial resolution. This image was used to build the DEM of the study area and extract the required data for the assessment of the flood-prone areas downstream the dam in the event of failure. The data were imported into ArcGIS software (version 10.5) to generate the final DEM and obtain additional mapping information such as watershed limits, hydrographic network used to define all the streams, altitude range, and relative position of slopes (Figure 3).

The flood simulation was realized using one-dimensional HEC-RAS model [32], which determined several physical characteristics of the flood wave including wave height, maximum flow 'Qmax' and velocity of the flood wave. HEC-RAS is undoubtedly one of the most used one-dimensional models that includes other applications such as water temperature modeling, sediment transport simulation, and since 2003, it was developed to simulate dam failure [33].

In addition to geomatic data described above, the simulation of the flood wave propagation downstream of the Yabous dam along Yabous river using HEC-RAS model was carried out using geometric, geotechnical and hydraulic data (boundary conditions) (Figure 3). 


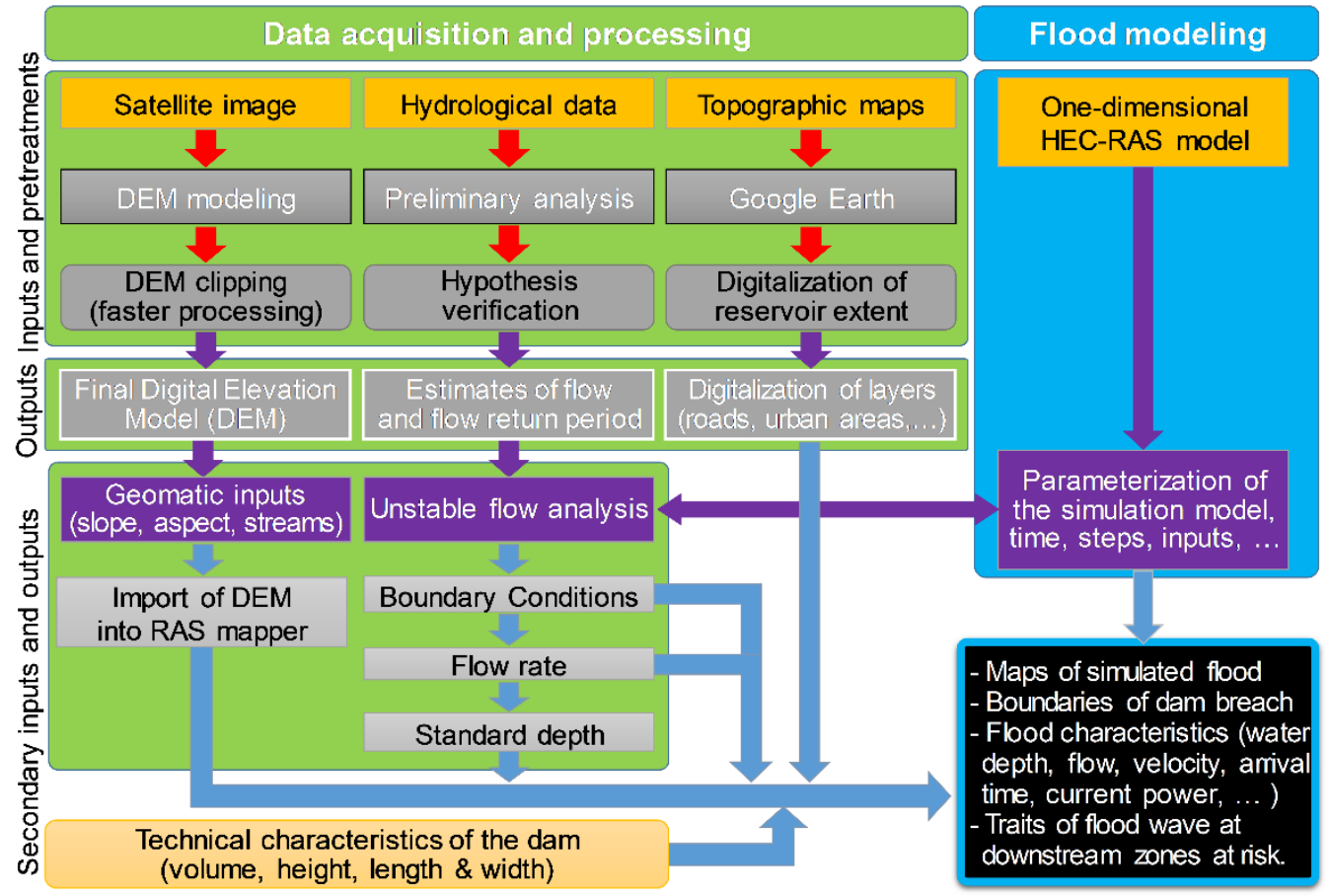

Figure 3. Methodological flowchart applied in Yabous watershed (NE Algeria) during the simulation of dam-failure flood using 1D HEC-RAS hydraulic model.

\subsubsection{Dam Dimension}

The body of Yabous dam has the form of a zoned earth dike with a watertight clay core. Its crest length is $480.00 \mathrm{~m}$ and its width is $7.00 \mathrm{~m}$. The central core of the dike (zone 1 ) is made up of clay materials. The upstream recharge consists of argillaceous colluvium and wadi alluvium. In addition, the downstream is made up of alluvial material from the wadi resting on a sand filter mat to protect the crumble, colluvial and marl foundation (Figure 4).

The embankments are protected by limestone riprap. The limestones are dense and contribute to the protection with their acceptable mechanical characteristics. The backfill's overall volume of the dam body is 1,418,810.00 m3. Regarding the accomplishments' description, there is a temporary tunnel-type diversion gallery of $373.00 \mathrm{~m}$ long and 7.00 $\mathrm{m}$ in diameter. The tunnel has a discharging capacity of the planned (millennial) flood qualified to $485.00 \mathrm{~m} 3 / \mathrm{s}$. More, a tulip-type spillway, with a well connected to the temporary diversion gallery ending in a stepped dissipation basin. The spillway is capable of evacuating the design flood. The outer diameter of the spillway's weir and that of the drum are $16.00 \mathrm{~m}$ and $7.00 \mathrm{~m}$, respectively. Last, a circular water intake tower and its access walkway, which comprises three (03) stepped water intakes and a bottom drain. 


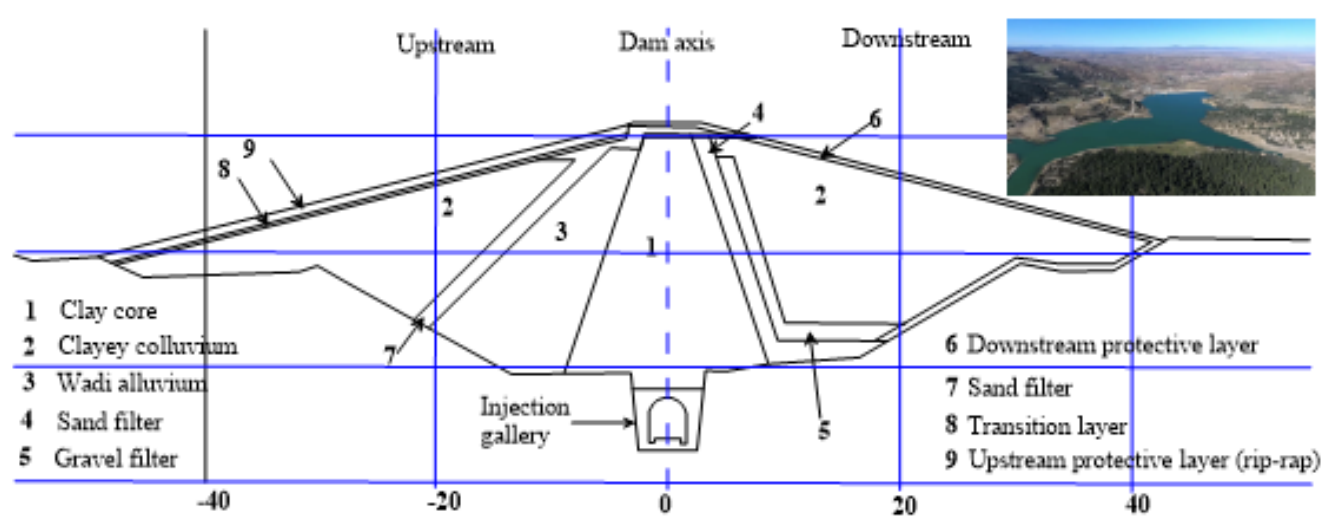

Figure 4. Dam dimension.

\subsubsection{Flood History}

The site experienced an exceptional flood, with a significant flow, on $08 / 22 / 2015$. The flow exceeds that of the project in terms of the dam body and its annexes. Mentioning as an example the designed intake tower, the spillway and the dissipation basin. The evidence was that the flow was able to occupy the section of the dissipation basin and even to discharge over its walls (walls). According to the figure 5, the flooding causes the deterioration of the following structures: (i) Drainage channel to the bottom drain: The gabion mat protecting the raft from the inlet channel to the bottom drain has been completely damaged (Figure 5a). (ii) Restitution channel at the outlet of the dissipation basin: The protective riprap of the dissipation basin's downstream part has undergone significant degradation. Identically, the massive support for the potable water and the irrigation pipes endured a serious damage (Figure $5 b$ ).

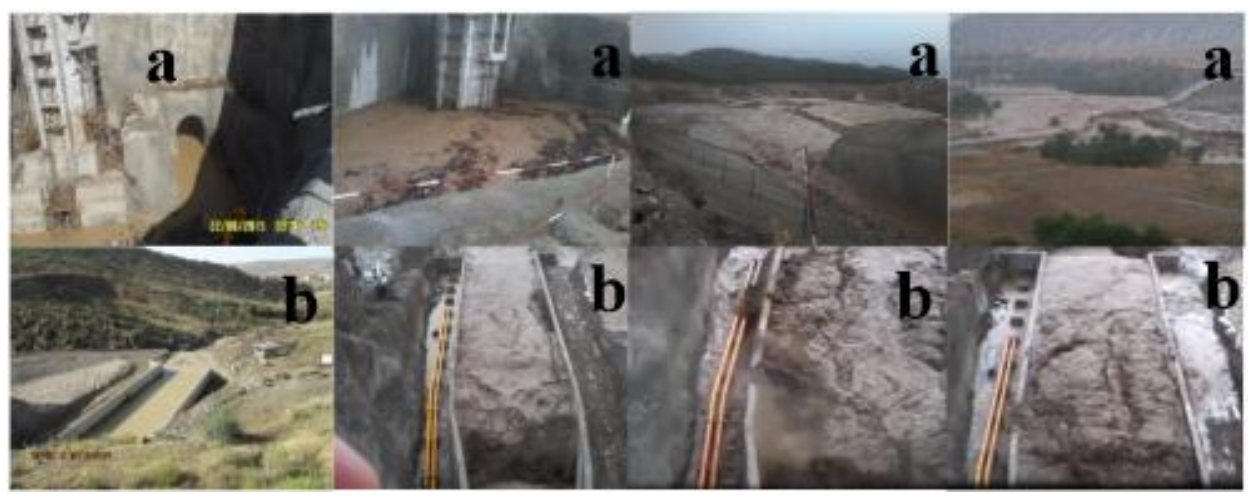

Figure 5. Flood historic of Yabous river. (a) The gabion mat protecting the raft from the inlet channel to the bottom drain has been completely damaged; (b) The protective riprap of the dissipation basin's downstream part has undergone significant degradation. Identically, the massive support for the potable water and the irrigation pipes endured a serious damage.

\subsubsection{Geometric Data}

Cross sections were placed along Yabous river in order to estimate the height of flood wave downstream of the dam at different sites, which were selected based on the change of the river's direction, width, slope and land uses such as agricultural lands, presence of urban areas and infrastructures such as bridges and roads. Cross-sections consisted of either a short section for a narrow valley or elongated section that functions whenever the simulated water level exceeds the height of that section. This pattern was implemented in order to ensure that the height of the flood wave resulting from a possible dam failure does not exceed the cross sections. Using RAS Mapper (version 5.0.7), the cross-sections were converted into points that were supplemented with elevation values 
retrieved from the DEM data and which are required for HEC-RAS analysis. Then, the model calculated the distance between each two cross-sections. A transversal quality control was carried out on the geometric data to ensure that no inexact information was imported. Accordingly, few cross sections were edited, if required, in the graphic cross section editor [34]. In total, 89 cross-sections were implemented on a total length of 12.3 $\mathrm{km}$ along Yabous river, with distance between two cross-sections ranged from 50 to 150 $\mathrm{m}$ ) and 1,267 cross-sections interpolated using the model to ensure a good simulation of the flood wave propagation downstream of the dam (Figure 6). Five sites located along an altitudinal gradient downstream the dam were selected to assess the impact of dam-failure flood i.e. (S1) axis of the dam, (S2) upstream urban area (Yabous town), (S3) bridge 1, (S4) bridge 2, and (S5) downstream urban area, which correspond to the cross-sections respectively: 9092, 8422, 7897.7, 5818 and 5733 .

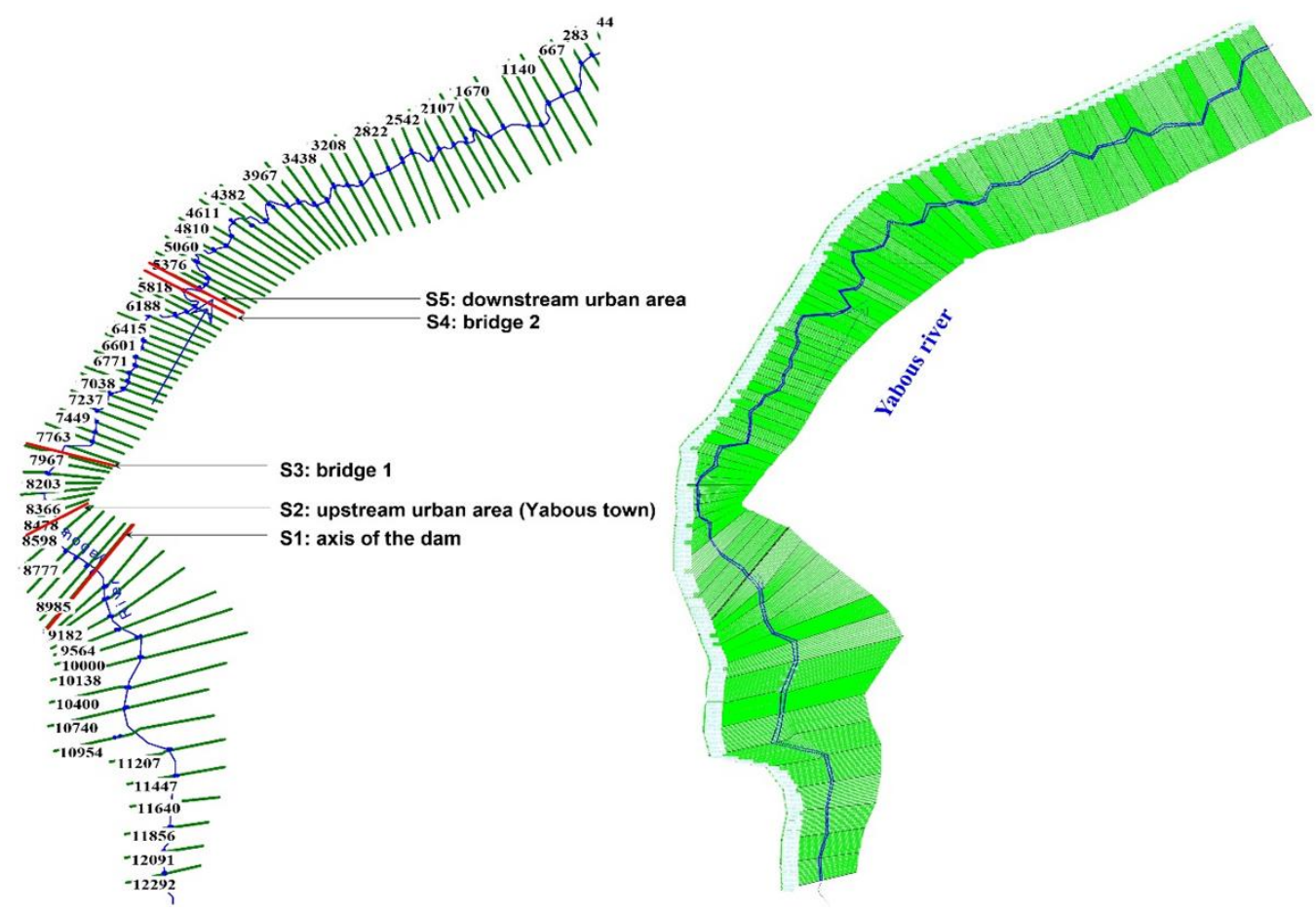

Figure 6. Location of cross-sections ( $n=89$, left plot) and interpolated sections ( $n=1267$, right plot) along the river downstream Yabous Dam in northeaster Algeria. Numbers represent the cross sections.

\subsubsection{Geological/Geotechnical Data}

The study area is part of the Eastern Saharan Atlas. The area's intermediate position between the Saharan platform and the mobile Tellian domain explains the facies variations it presents (Figure 7). The Cretaceous formations characterized by the internal platform facies on the southern and southwestern margins of the basin pass to marl-limestone series to faunas and pelagic micro-faunas toward the north and northeast. The Yabous dam site is based on a tectonic accident stalling in an NS direction, which may present a certain issue concerning its stability. The town of Yabous is located at an altitude of $900-1100 \mathrm{~m}$ and delimits the "Aurès" massif to the north. Its surface is covered by a Quaternary piedmont glacis, largely encrusted, which hides a powerful series (approximately $700 \mathrm{~m}$ ) of sandstone sediments dated from the Tortonian Miocene. The locality of Yabous presents several types of fault structures from both pre and post-Miocene era. The latters appeared in Cretaceous and Miocene formations.

Due to its high precision, the Manning's roughness coefficient was used in the HEC-RAS hydraulic model to compute water surface elevation. According to the classi- 
fication of [35], two types of land use classes were selected for the study area. Then, the values of Manning's coefficient were adapted according to this classification. The Yabous river bed is made of uniform gravels with rugged banks. According to the Chow's classification of the river substrate, a Manning coefficient value of 0.0356 was retained for the entire river bed in the study area. However, the Manning coefficient of agricultural land on the left and right sides of riverbed is 0.1 .

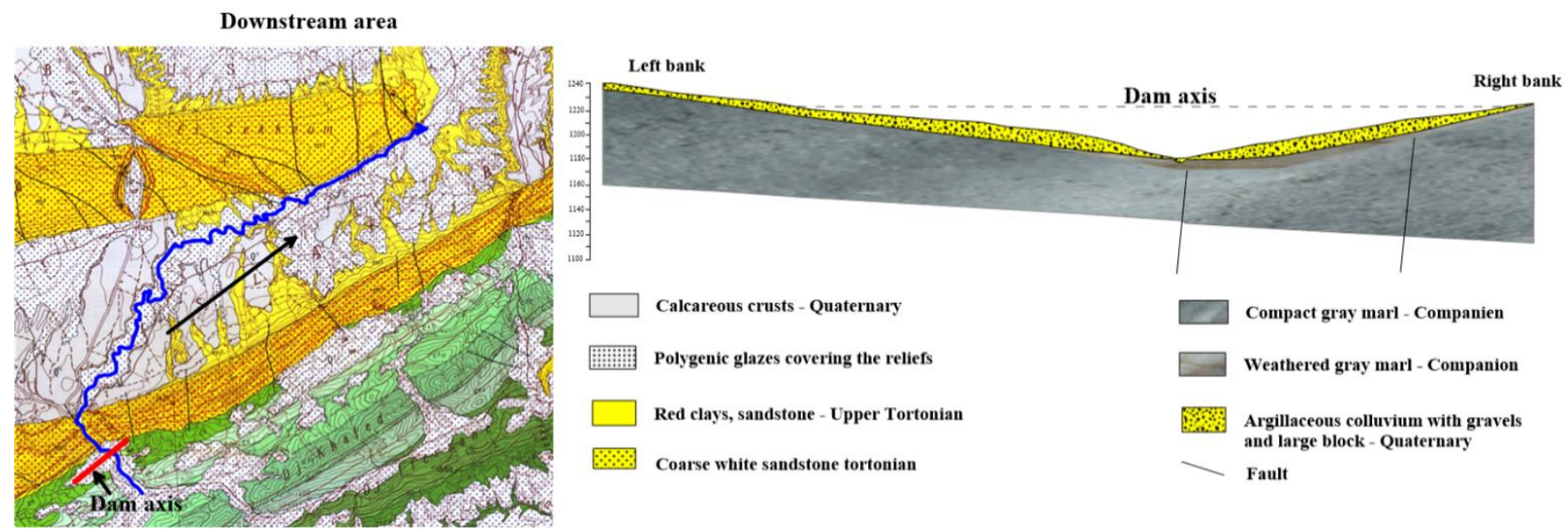

Figure 7. Geological maps of the study area "Yabous watershed" located western the Province of Khenchela (bottom left map) in northeastern Algeria.

\subsubsection{Hydraulic Data}

After the processing of geometric data, the initial and boundary conditions required for the HEC-RAS model were: First, (1) the initial condition $\left(\mathrm{Q}=3 \mathrm{~m}^{3} / \mathrm{s}\right)$. Second, (2) data of the millennial series flood hydrograph with a maximum discharge of $485 \mathrm{~m} 3 / \mathrm{s}$ (Figure 8 ). Third, (3) the normal depth value that was obtained from the slope and calculated from the profile of the river using HEC-RAS model. The normal depth of Yabous River, in this study, was established at 0.002. Once the previous information were settled and data processed, the model was launched to simulate the propagation of flood wave downstream the dam.

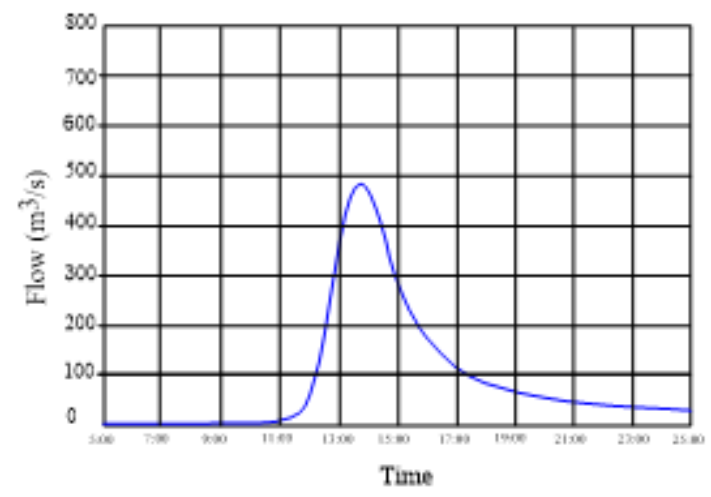

Figure 8. Flood hydrograph of Yabous river.

\subsection{Estimation of Dam-Breach Parameters}

Risk assessments of embankment dam failure frequently require the prediction of the basic temporal and geometrical parameters of a breach in order to estimate peak breach flows. This flow varies following breach parameters such as the width, slope and time of breach formation [36]. The most used models predicting these relationships have been developed from statistical analyses involving historic data of dam failures. The prediction uncertainties of these methods are broadly large, but still never concretely 
quantified [23]. Among many methods used to predict the parameters of dam-breach, four methods were selected in this investigation [37-40] (Table 1). Regarding the adaptation of these methods for the regression analysis, a prediction analysis of these methods is important to estimate their performance. For example, Froehlich $[39,40]$ used parameters of 63 dam-breach cases to develop their relationships, whereas Von Thun and Gillette [38] used 57 dam-breach cases, and Macdonald and Langridge-Monopolis [37] used 42 dam-breach cases. The use of uncertainties of breach parameter estimates obtained from one of these methods is necessary to determine their impacts on the risk of dam failure. These uncertainties are assessed so that reasonable limits of breach parameter values can be estimated and used to determine the reliability of the flood hydrograms predicted by the hydraulic structures as well as the flood wave peaks at the defined sites downstream the dam. The four above mentioned methods exist in the model HEC-RAS version 5.0.7. The HEC-RAS model was used to calculate the average width, lateral slope and the breach formation time for each method once its requirements and input data were filled.

As the HEC-RAS model requires a certain amount of input data, a sensitivity analysis was carried out in order to quantify the importance of the different involved quantities [18]. In the current study, breach formation refers to several parameters including breach width, breach slope, and the time of breach formation. While for the propagation of the flood wave downstream, a breach involves several physical and hydrodynamic parameters such as: flow velocity, width and height of the flood wave. For this effect, in order to highlight the influence of the breach formation parameters on the flood wave physical and hydrodynamic parameters associated to dam-failure flood, a sensitivity analysis method of four adjustments $(-50 \%,-25,+25$, and $+50 \%)$ was used for each of the selected sites at flooding risk. The application of this method aims to thoroughly clarify the trend of each breach parameter on each parameter of the flood wave in every downstream section selected along the flood course.

In order to demonstrate how flood wave performed for different levels of breach adjustments $(-50 \%,-25,+25$, and $+50 \%)$ of breach parameters (slope, width and formation time), relationships between flood wave flow, width, and height were tested using generalized linear mixed-effects models (GLMM), with Gaussian distribution error and 'identity' link. The selected sites downstream Yabous dam were considered as random effects, whereas flood wave variables (height and width) and breach adjustment levels were the fixed-effects terms. The GLMMs were carried out using the package $\{$ nlme $\}$ in $R$ [41]. For each breach parameters (slope, width and formation time), three GLMMs were conducted to test the effects flood wave width on wave flow and wave height, and the effect of flood wave height of wave flow. The $R$ package \{ggplot2\} was employed in plotting data of the dam-breach parameters.

\section{Results}

\subsection{Estimate of Dam-Breach Parameters}

Dam-breach parameters including average breach width, breach side slope and failure time were predicted. After computing these parameters using the available methods in HEC-RAS, the obtained results were reviewed then a single predicted value was selected. These recommended values are shown in Table 1. 
Table 1. Parameters of the flow simulation for four dam-breach parameter predicting methods using the HEC-RAS in modeling dam-break flood of Yabous dam in northeastern Algeria.

\begin{tabular}{lcccc}
\hline & \multicolumn{3}{c}{ Flow parameters } \\
\cline { 2 - 5 } Predicting methods of dam-breach parameters & Width (m) & Slope & Flood Time (h) & Q (m³/s) \\
\hline Macdonald and Langridge-Monopolis (1984) & 14 & 0.5 & 1.10 & 4400.18 \\
Von Thun and Gillete (1990) & 54 & 0.5 & 0.47 & 8767.87 \\
Froehlich (1995) & 26 & 1.4 & 0.40 & 7841.12 \\
Froehlich (2008) & 26 & 1.0 & 7363.03 \\
\hline
\end{tabular}

\subsubsection{Breach Width}

The dam-breach parameters analysis described earlier showed that the Froehlich methods produced comparable results for this scenario, in which average breach width (Bavg) was relatively moderate $($ Bavg=26m). However, the Macdonald and Langridge-Monopolis (1984) method underestimated the observed breach width as its showed the lowest values (Bavg=14m). The Von Thun and Gillette method recorded the highest value (Bavg $=54 \mathrm{~m})$. The prediction intervals developed through these methods were sobering for this case study aiming at obtaining a definitive result because the results obtained varied from small values through the dam to high values for breach width. Accordingly, the results of Macdonald and Langridge-Monopolis method were excluded in this case study due to the low values.

\subsubsection{Breach Time}

Failure time predictions are summarized in Table 1. All the methods indicated a short time (40-47 $\mathrm{mn}$ ) to empty the reservoir during the simulated dam-failure event, except for Macdonald and Langridge-Monopolis method, which predicted a slight longer time=1.1 h. According to the failure time obtained in all predicting methods, the dam-break analysis showed that the flood wave associated to simulated dam-break developed very fast. Accordingly, the consequences of this flash flooding are expected to be catastrophic and irreversible if a very early warning system is not installed for alerting the citizens inhabiting this flood-prone zone.

\subsubsection{Flow Peak}

Peak outflow estimates are shown in Table 1, sorted in order of increasing peak outflow for dam-breach break scenario. The lowest peak flow predictions were obtained using the method with the least parameters. The highest peak flows were predicted using equations that incorporated a significant dependence on breach parameters. According to this analysis, a convergence was observed between results obtained using Froehlich methods [39,40] and those of Von Thun and Gillete method [38], with point-flow values were $7841.12 \mathrm{~m}^{3} / \mathrm{s}, 7363.03 \mathrm{~m}^{3} / \mathrm{s}$ and $8767.87 \mathrm{~m}^{3} / \mathrm{s}$, respectively. However, a significant difference was detected between results of these methods and outputs of Macdonald and Langridge-Monopolis method [37] (Q=4400.18m³/s) (Table 1).

\subsection{Analysis of Dam-Breach Food Scenario}

Hydrodynamics of the flood wave along Yabous river during the simulated dam failure followed four steps (Figure 9). The first was (1) upstream the dam. The second, (2) 
on the dam reservoir. The third, (3) at the level of breach formation, and the fourth was (4) downstream right from the dam to the end of the river.

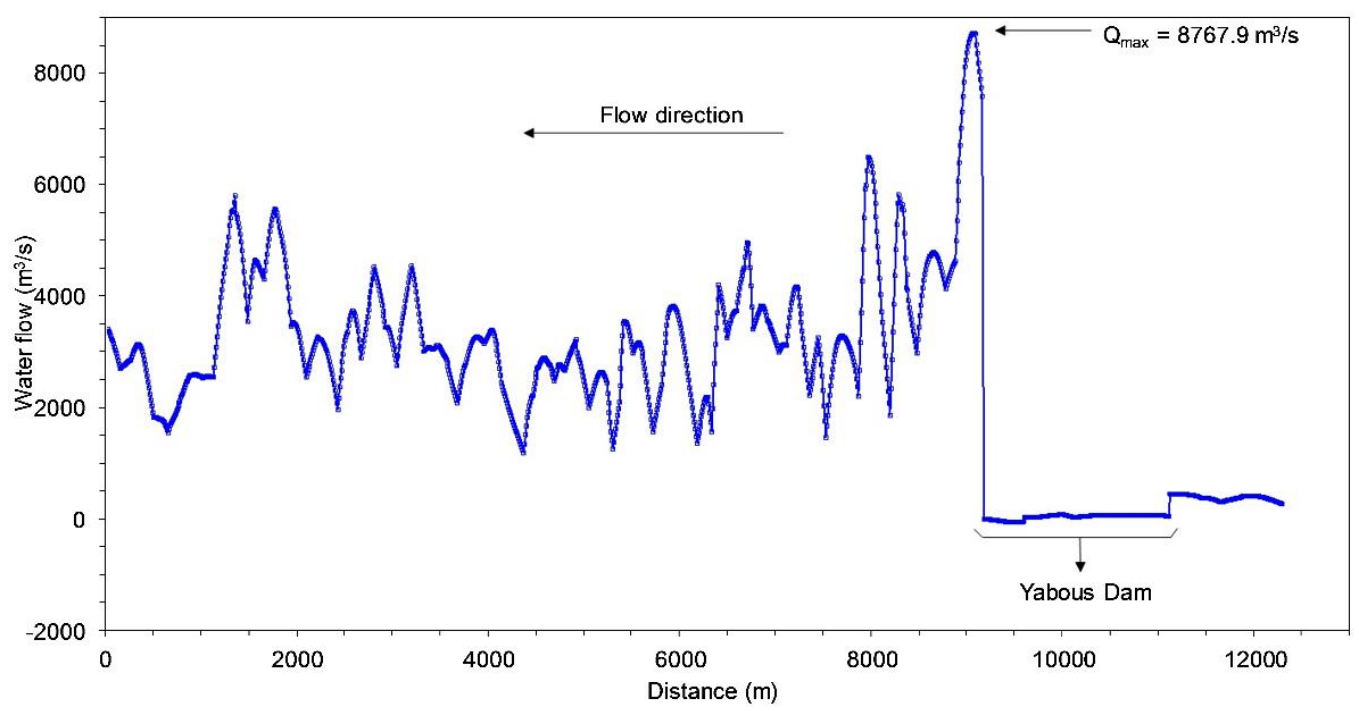

Figure 9. Flood hydrograph of dam-failure flood applied to Yabous dam using the Von Than and Gillet method.

Dynamics of the maximum flow velocity was mapped for the dam failure scenario depending on verified results of the one-dimensional hydrodynamic model (Figure 10). Regarding the flow velocity, two types of flows are distinguished during Yabous dam-break flood. Velocity curve can be divided into three main parts; the parts $\left(\mathrm{I}_{\mathrm{a}}, \mathrm{Ib}\right)$ reflected a torrential flow, while part (II) indicated a fluvial flow.

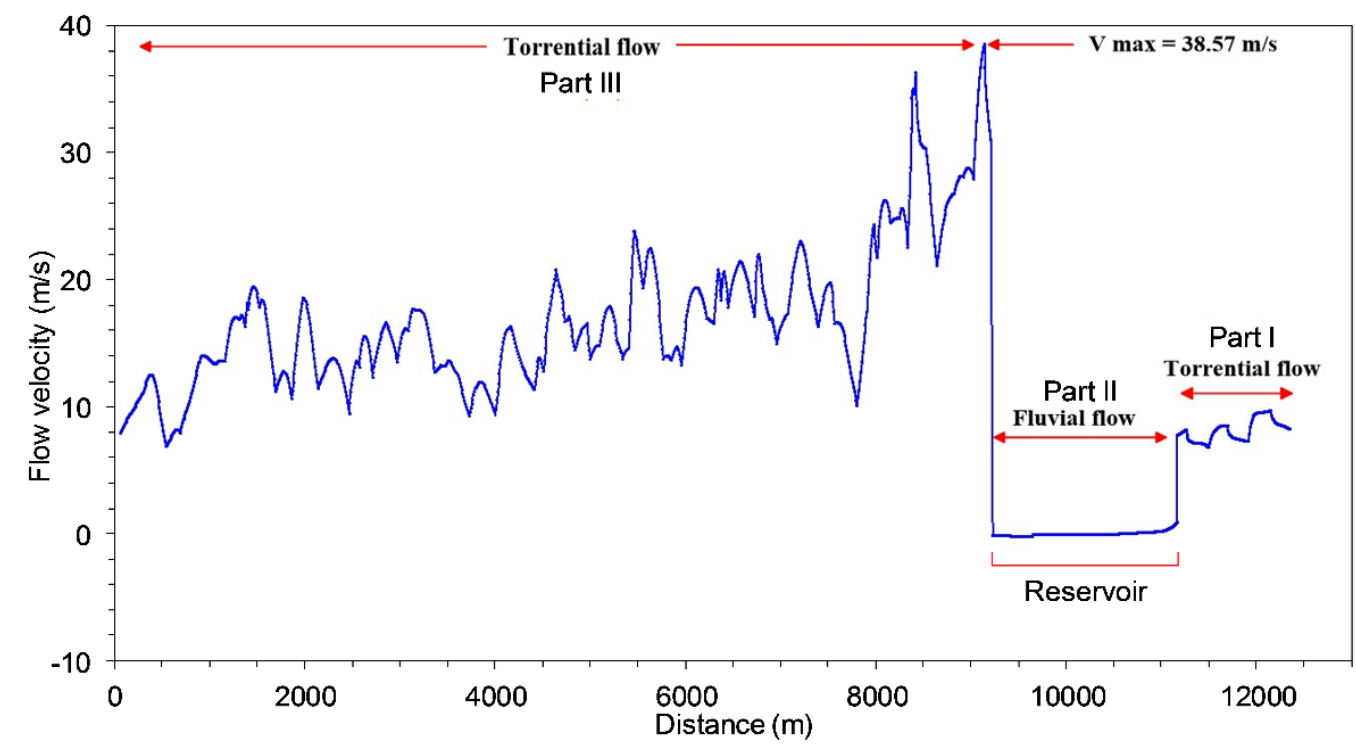

Figure 10. Dynamics of flow velocity during dam-failure flood of Yabous dam along the river downstream.

Changes in width of the flood wave corresponded to the geometry of the basin along the Yabous river (Figure 11). For steep slopes, narrow widths were recorded as the point of breach formation on the dam axis. Whereas the large widths recorded at weak slopes can be related to the slowing down of water flooding at these slopes where the maximum width (Breservoir $=1028.18 \mathrm{~m}$ ) was recorded at the level of the dam reservoir, just a few seconds before the dam failure. At that moment, the height of the water in the dam reservoir was equal to the height of the dam. The satellite image and the cross section show 
water filling the reservoir behind the Yabous dam (Figure 11). Actually, data represented in Figure 11 indicated a hydrodynamic trending in the opposite direction compared to data showed in Figures 9 and 10, which represent the flow and velocity of the flood wave before and during the dam failure. Therefore, we can argue that Figures 9 and 10 reflect the potential energy of flood wave, whereas Figure 11 represents the quantitative energy of flood wave at each point along the Yabous river.

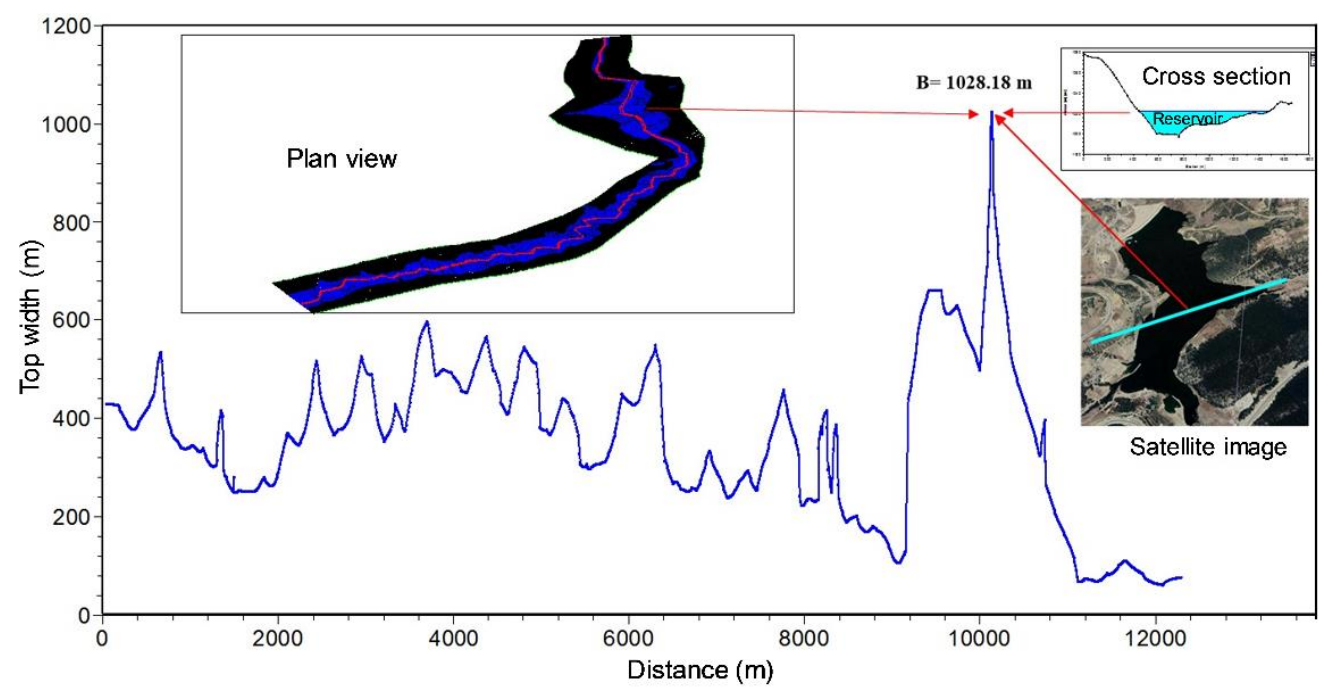

Figure 11. Hydrodynamic of the width of the flood wave along Yabous river during simulated dam-failure flood.

The profile of water current power evolved similarly with trends of water current shear stress, which represented the potential energy of the water during the flood. The two previous profiles were developing in the opposite direction to that of the surface (Figure 12). During the time of dam failure, no dynamic was recorded at the level of the dam reservoir, which is due to the stabilization of the water level in this part. However, the flow peak was observed at the level of the breach formation, where water was falling from the reservoir with the progressive formation of the breach. Meanwhile, irregularities were observed along the sections of Yabous river for the three main factors, viz. the change in land slope (geometric), the type of soils/rock outcrops of this zone (geotechnical) and the type of flow either in load or in suspension (hydraulic). 


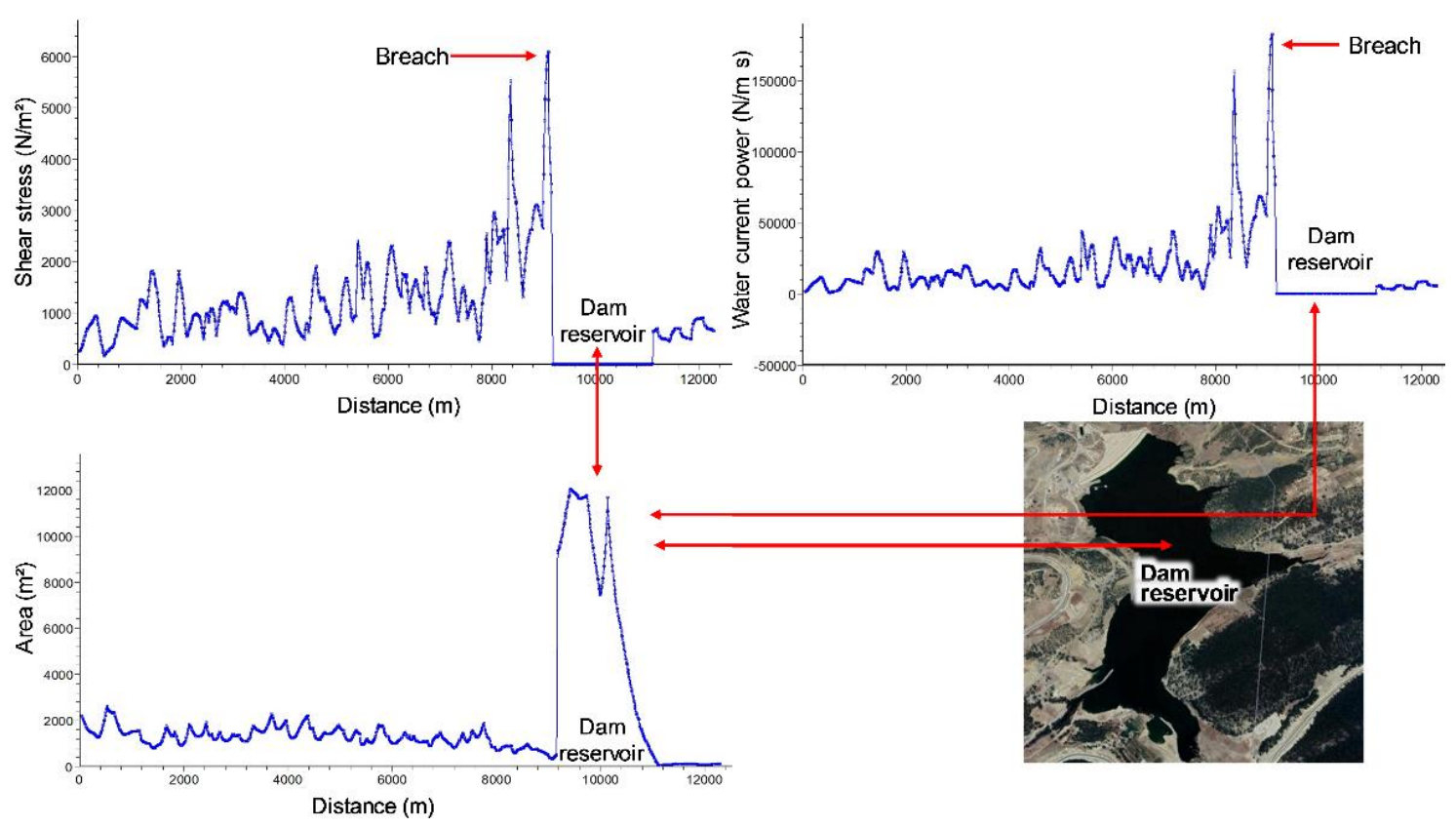

Figure 12. Power, shear stress and water surface of water current associated with the flood wave along Yabous river during simulated dam-break flood.

The analysis of flood wave propagation along the Yabous river during the simulated dam failure using the HEC-RAS model showed that the flood wave dynamics have four parts (Table 2, Figure 13, 14). The first, (1) before dam failure (time=00:00 h), where the reservoir is filled to the standard level. The second, (2) after 30 minutes of dam failure, the flood wave arrived the entrance of the Yabous village. The third, (3) right after one hour from reaching Yabous entry, the flood wave reached the exit of the urban area. The fourth, (4) during a time equal to 01:30 h after the dam failure, the reservoir was emptied completely. 

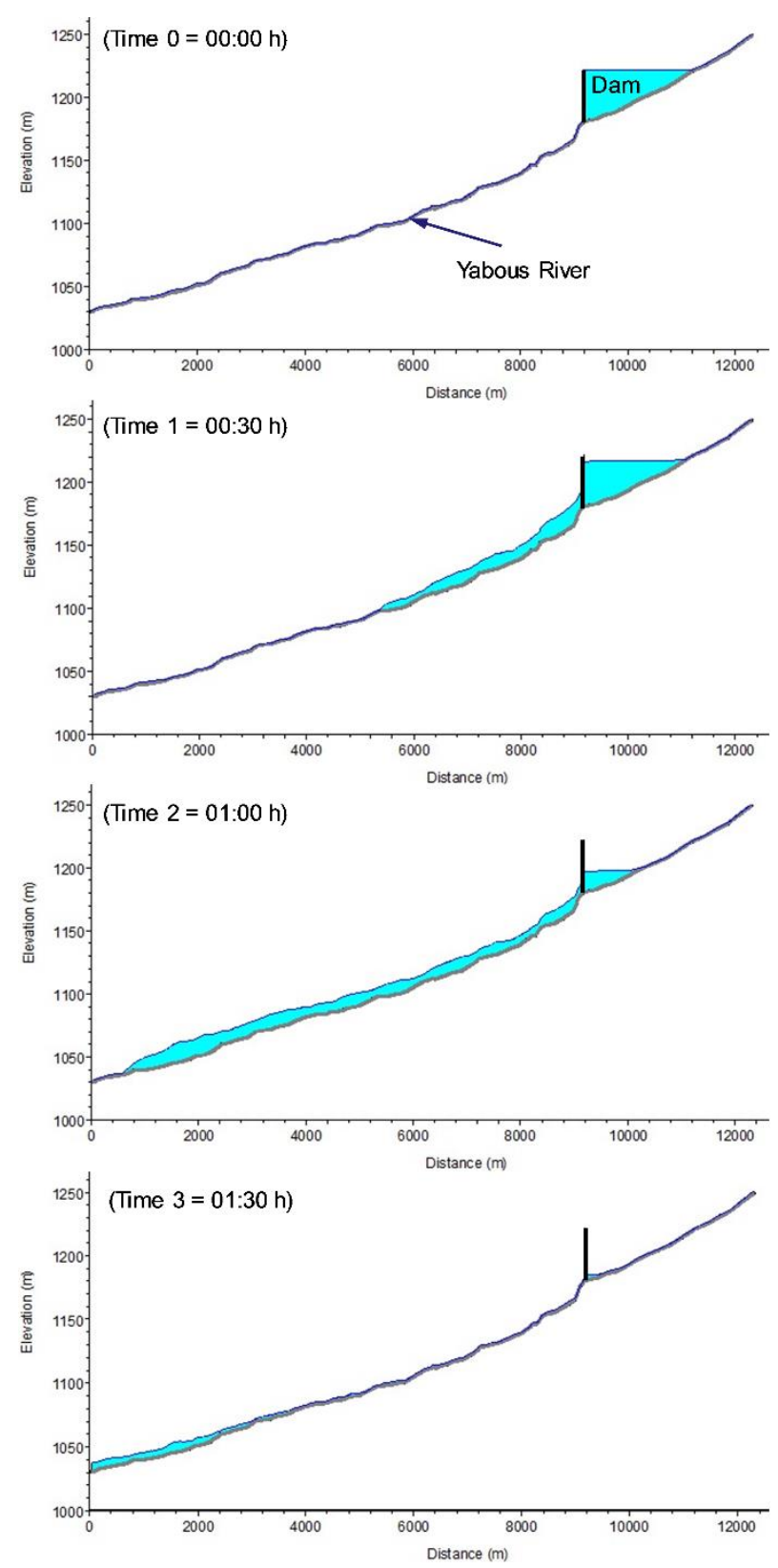

Figure 13. Longitudinal profile of the flood wave propagation before, during and after the simulated flood of the Yabous river using 1D HEC-RAS hydraulic model.

Eventually, the dam dead storage volume of the reservoir remained and the flood wave started to fade. The frightening issue here is the high risk associated with this very quick discharge of a volume of 7 million $\mathrm{m}^{3}$ of the reservoir in only $90 \mathrm{mn}$. Although damage estimation was mostly based on water volume instead of depth [42]. It is worth mentioning that this eventuality represents a serious risk since flood-driven by dam-failure can cause serious and irreversible disastrous consequences to human populations settled in downstream areas as their socioeconomic and environmental livelihoods are devastated. Still, the travel time of a flood wave and the extent of flooding that would result from a dam failure should be predicted in order to prepare emergency action plans that would be used in the event of an actual dam failure [43]. Inundation maps developed in such simulation studies can serve as the core tool for decision making during the elaboration of emergency evacuation plans in the same way as in natural hazard assessment studies. These kinds of predictions have the potential to be a reference for future dam-break inundation practical applications and research studies [34]. Table 2 includes physical and hydrodynamic parameters of the flood wave for different sites selected 
along the Yabous river at the flood-prone zone downstream of the dam (Figure 14) in order to assess the impact of simulated dam-failure flood.

Table 2. Physical and hydrodynamic parameters of the flood wave for different sites (S1-S5) selected for assessing the impact of dam-break flood along the Yabous river in northeastern Algeria.

\begin{tabular}{|c|c|c|c|c|c|}
\hline \multirow[b]{2}{*}{ Flood parameters } & \multicolumn{5}{|c|}{ Sites* } \\
\hline & S1 & S2 & S3 & S4 & S5 \\
\hline Flood wave parameters & 9056 & 8422 & 7897.7 & 5818 & 5733 \\
\hline Maximum flow ' $\mathrm{Q}^{\prime}\left(\mathrm{m}^{3} / \mathrm{s}\right)$ & 8767.87 & 3603.6 & 3732.47 & 2427.49 & 1579.2 \\
\hline Minimum main channel elevation (m) & 1180.00 & 1153.46 & 1137.28 & 1100.65 & 1100.13 \\
\hline Water surface elevation (m) & 1194.05 & 1165.89 & 1146.97 & 1107.47 & 1106.98 \\
\hline Energy grade line elevation $(\mathrm{m})$ & 1223.87 & 1181.42 & 1155.62 & 1109.45 & 1107.72 \\
\hline Energy grade line slope $(\mathrm{m} / \mathrm{m})$ & 0.043532 & 0.046506 & 0.036115 & 0.014848 & 0.007767 \\
\hline Velocity (m/s) & 38.57 & 30.98 & 22.34 & 11.23 & 7.78 \\
\hline Surface $\left(\mathrm{m}^{2}\right)$ & 990.72 & 1394.43 & 1757.35 & 1102.46 & 1139.24 \\
\hline Width (m) & 129.96 & 213.85 & 357.17 & 354.88 & 312.54 \\
\hline Height (m) & 14.05 & 12.43 & 9.69 & 6.82 & 6.85 \\
\hline Froude Number & 2.75 & 2.84 & 2.38 & 1.44 & 1.01 \\
\hline
\end{tabular}

(S1: axis of the dam, S2: upstream urban area (Yabous town), S3: Bridge 1, S4: Bridge 2, S5: downstream urban area) 

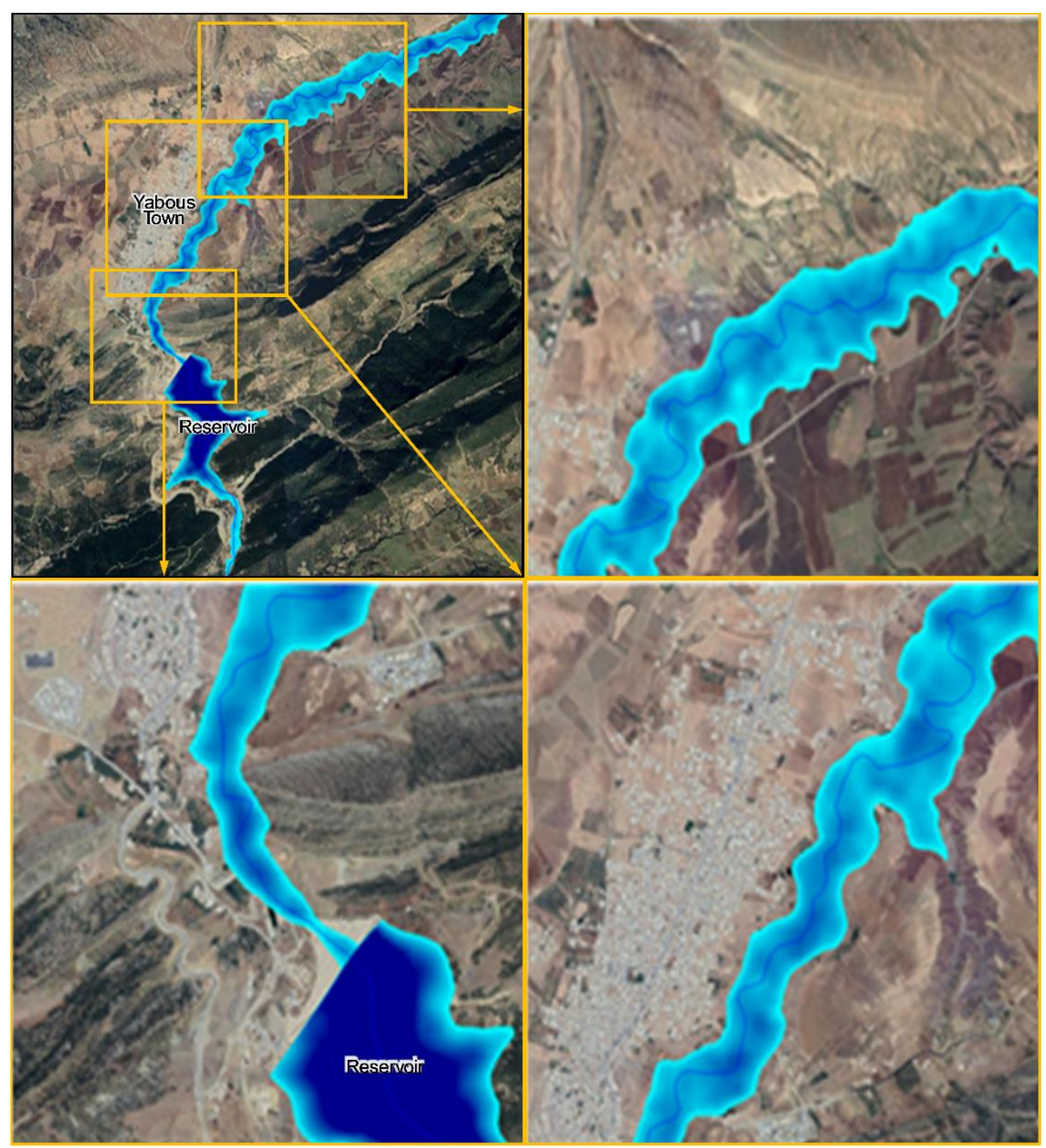

Figure 14. Satellite images showing flood-prone zones downstream of the Yabous dam at high flood risk associated to simulated dam-failure using 1D HEC-RAS hydraulic model.

\subsection{Sensitivity Analysis}

Figure 15 illustrates the variation of flood wave parameters (flow, width and height) for four adjustments $( \pm 25$ and \pm 50 ) of each breach parameter in five sites downstream Yabous dam, with the initial dam failure analysis (without adjustments) given in the plot in green color as a reference value (0). An important deviation of the four adjustments was observed for breach parameters compared to the analysis of this scenario without adjustment (0). Null result was obtained in all parameters modeled in this analysis. This demonstrates the significant nature of breach parameters on physical parameters of the flood wave associated to dam-break flooding.

Similar trends were found between breach slope and breach width with the four adjustments $( \pm 25 \%$ and $\pm 50 \%)$ as shown in Figure 15 . Values of physical and hydrodynamic parameters of the flood wave on the five selected sites decreased with the increase in adjustment values of breach parameters $(-25 \%,-50 \%)$. Whereas, flood wave physical and hydrodynamic parameters increased with the increase in adjustment values of breach parameters (i.e. $+25 \%$ and $+50 \%$ adjustment). Despite the similar trends obtained between breach slope and breach width, differences still remain for the adjustment values. Values of breach width for the four adjustments were higher than those of breach 
slope. This indicates the large impact of the breach width values on flood wave parameters (Figure 15,16). The underestimation of breach width or breach lateral slope can lead to unsatisfactory results according to Singh and Scarlatos [18], particularly in earthen dams which consist of several building materials.

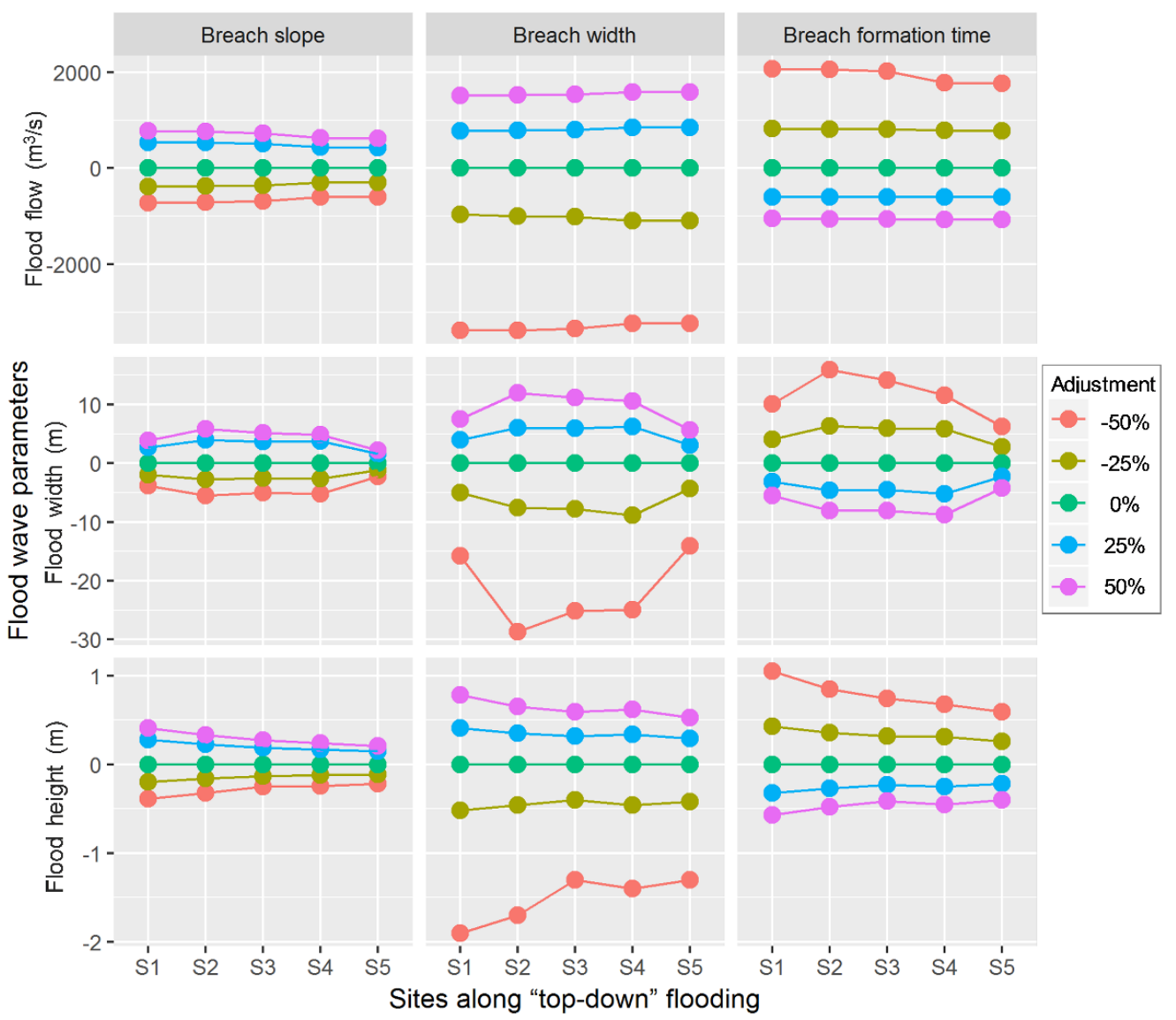

Figure 15. Results of sensitivity analysis of dam-breach parameters (flood flow, width, and height) showing various adjustments of the breach slope, breach width and breach formation time for different sites (S1-S5) selected along the Yabous river in northeastern Algeria for appraising the simulated dam-break flood. 

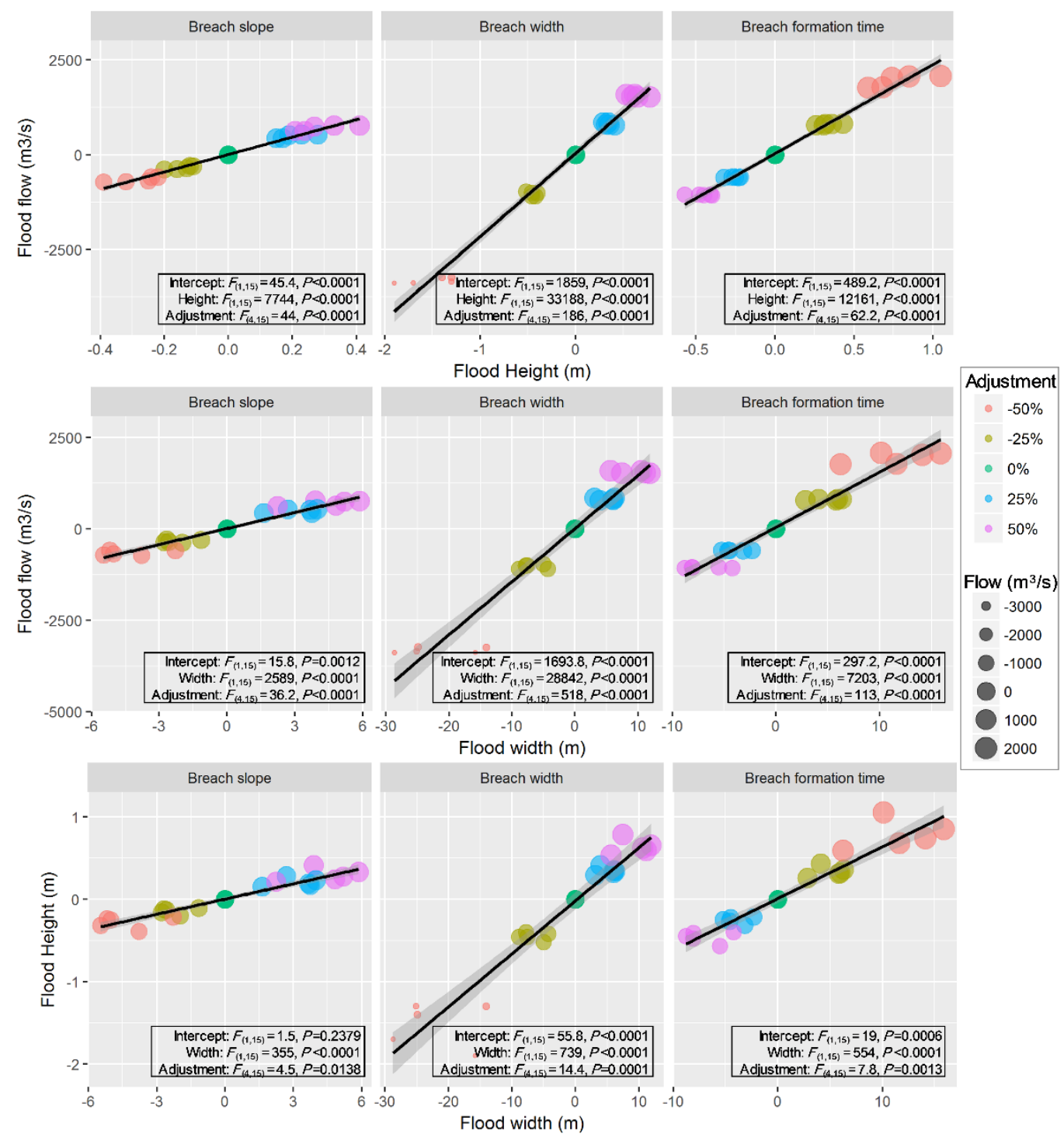

Figure 16. Relationships between simulated flood wave parameters (flood flow, width, and height) for various adjustments of the breach slope, breach width and breach formation time simulated at Yabous river in northeastern Algeria. Point sizes are set to water flow values and the color mapped to the levels of breach adjustments $(-50 \%,-25,+25$, and $+50 \%)$. The black solid lines represent linear regressions obtained by a Gaussian GLM (generalized linear model) fit with $95 \%$ confidence regions in light grey. Statistics reported in the boxes are results of fixed-effects terms of GLMMs, with F-statistics and P-values are type-I tests 'sequential'. Figures between brackets represent numerator and denominator degrees of freedom, respectively.

\section{Discussion}

Four methods were used in this work: MacDonald and Langridge-Monopolis [37]; Von Thun and Gillete [38]; Froehlich [39,40] for the determination of the dam-breach parameters. The results for the four methods for the all parameters have different (Table 1). This difference can be explained by the lack of necessary data for the estimation of breach parameters. On the one hand, this reflects the reliability of the results obtained using the first three methods for the estimation of breach parameters including width, slope and time of breach formation and the simulation of flood wave propagation downstream following dam-failure, on the other hand. Macdonald and Langridge-Monopolis' method can no longer be adopted for a full study because of its aberrant and unreal results. Overall, Froehlich's methods showed good results in the field. It remained the best method in this field, given the high number of real dam-failure cases 
(63) used while predicting dam-breach parameters, and because it is the most suitable for earthen dams [44]. The methods offered by Froehlich $(1995,2008)$ distinctly had the best prediction performance in the uncertainty analysis (Table 1). These methods had the smallest mean prediction error and the narrowest prediction interval by a significant margin [23,45]. Results of Von Thun and Gillete's method highlighted the worst flood case with high flow level $\left(\mathrm{Q}=8767.87 \mathrm{~m}^{3} / \mathrm{s}\right)$ (Figure 9). This clearly indicates the limits of the risk zone downstream the dam. The dam-breach break scenario proved to be a large case event when analyzed by this method, so the peak outflow is expected to occur when the breach had reached its maximum size before the occurrence of a significant drawdown in the reservoir.

For the hydrodynamics of the flood wave along Yabous river during the simulated dam failure followed four steps. For the step (1), a weak hydrodynamic of the flood wave upstream of the dam was represented by a flow hydrograph given to the HEC-RAS model as a condition at the upstream limit with a flood rate (Qmax=485 $\mathrm{m}^{3} / \mathrm{s}$ ). For the step (2), no water dynamic was observed at the entire length of the dam reservoir because of the stability of water level in the reservoir. In step (3), water discharge began at dam crest during dam-break with a very slow flow. A significant development was recorded during the breach formation. This reflects the discharge of reservoir waters in the event of a rupture on a small breach that begins to form gradually during the dam rupture, where flow recorded a peak $\left(\mathrm{Qmax}=8767.87 \mathrm{~m}^{3} / \mathrm{s}\right)$. Given the large water quantity discharged over the dam crest, the propagation of the flood wave downstream the dam is seriously hazardous and may have irreversible and disastrous consequences on urban areas, local populations and the environment with heavy economic losses [28]. For the step (4), the dynamics of the flood wave downstream dam sinuated. This is most likely because slope changes along Yabous river, on the one hand. On the second hand, the basin section widens for each point of the river. According to the time of breach formation $(0.47 \mathrm{~h})$ and the geometry of the breach (flood width=54 m, slope=0.5), the flow peak of the flood wave propagated very quickly downstream (Figure 9).

Regarding the flow velocity, two types of flows are distinguished during Yabous dam-break flood ( $\mathrm{I}_{a, b}$ and II). Part $\mathrm{I}_{a}$ represents the flood hydrograph given to the model as a condition at the upstream limit (S0). More, It extended from section (S0) to the beginning of the dam reservoir with an average velocity ( $\mathrm{V}=9 \mathrm{~m} / \mathrm{s}$ ). For part II, it represented the fluvial flow velocity over the length of the dam dike with almost zero velocity. This flow resulted from the dissipation of flow energy by the stable water of the dam reservoir. Regarding part $\mathrm{Ib}$, it indicated the torrential flow which reflects the potential energy of the flood wave from the formation of the breach on the dam to the final section of the study area (Figure 10). The flow torrentiality is due to the change in the slope of the river on the whole part $(\mathrm{Ib})$. Indeed, the flow velocity increases rapidly in the wave tip zone, where the flow resistance dominates [46,47]. High velocity peaks represent steep slopes, where flow speed recorded the highest velocity at the level of the breach formation $(\operatorname{Vmax}=38.57 \mathrm{~m} / \mathrm{s})$. The low peaks represent the weak slopes where small reservoirs occurred naturally and contributed to the dissipation of water flow on the river. The flood wave velocity shows a better match with the DEM model implanted in HEC-RAS. This analysis can provide a reasonable approximation of the impacts of flood wave on areas located downstream in the event of dam failure. Thus, this information is essential for flood hazard classification and developing emergency action plans [47].

The simulation of the flood wave propagation downstream of Yabous river was carried out using the 1D HEC-RAS model delineated the zone that can be affected by this flood wave downstream the dam in case of the latter's failure. The flood wave related to dam-failure recorded at the breach level a flow point of $Q=8767.87 \mathrm{~m}^{3} / \mathrm{s}$ and this reflects the impact of this flood downstream of dam (Table 2). Subsequently this wave arrived at site S2 $\left(\mathrm{N}^{\circ}\right.$ 8422) which represents the beginning of Yabous village with a flow and a 
flood-wave width of $Q=3603.60 \mathrm{~m}^{3} / \mathrm{s}$ and $B_{\text {Flood }}=213.85 \mathrm{~m}$, respectively. This width confirms that the upstream limit of the Yabous village far from this flood (Figure 14). The flood wave reached Site S3 at the first bridge with four square openings $(3 \mathrm{~m} \times 3 \mathrm{~m})$ with a flow of $Q=3732.47 \mathrm{~m}^{3} / \mathrm{s}$, flow width=357.17 $\mathrm{m}$ and a height $=9.69 \mathrm{~m}$, which is expected to completely submerge the bridge (Table 2). This demonstrates the violent and destructive impact of the rapid flood resulted from dam failure. The wave arrived at the second three-opening bridge $(3 \mathrm{~m} \times 3 \mathrm{~m})$ located downstream the village $\left(\mathrm{S} 4: \mathrm{N}^{\circ} 5818\right)$ with a flow $\mathrm{Q}=2427.49 \mathrm{~m}^{3} / \mathrm{s}$ and a height $\mathrm{H}=6.82 \mathrm{~m}$ which may induce the total damage to this bridge and thus cuts the road relating the town of Yabous to the Khenchela City. The flooding caused by dam failures in an urban area is a complex phenomenon, specifically with the appearance of structural ruptures, suspended debris and incisal currents, especially when associated to a very unstable and turbulent flood flow $[48,6]$.

The flood wave came out Yabous town with a flow $=1579.20 \mathrm{~m}^{3} / \mathrm{s}$ and width=312.54 $\mathrm{m}$. These findings support the real need of protecting the local population and their livelihood from possible flood events generated from dam failure. Heavy human and economic losses are expected with the rapid passage of the flood wave. This includes the partial destruction of the urban zone, agricultural lands and crops located downstream. The analysis, also, demonstrated that because of dam-break flood event, the town of Yabous may lose some houses built on the left edge of the Yabous river (Figure 14). Despite the acceptable protection status of Yabous town against this simulated flood, the flood wave is expected to seriously harm the region at various levels. Such as all the flooded agricultural lands, which are expected to be severely destroyed and lose their productivity feature. Hence, crop yields get destroyed, too. Agricultural activities and livestock farming represent a large part of this area population income. More than 80,000 different ( $80 \%$ are apple) can be affected by this flood event.

Ecologically, the passage of flood waves is often associated with detritus deposit and drastic change of soil characteristics. All this is expected to disrupt the behavior of fauna and flora and the entire ecosystem functioning of the region [49-52]. The negative effects on flora and riparian river habitats are projected to be severe and most likely persistent throughout the risk area [53]. Simulation analysis can measure the extent and the intensity of the damage caused by the deposits of solid residues (tailings, metals, plastics, woods, ...) transported with the flood wave, of which the loss of vegetation would trigger a bottom-up control of land degradation [54]. Consequently, the loss of soil stability and runoff control increases the risk of further geomorphological disturbances, including landslides, bank ruptures and massive creep movements. To this end, the priority is given to mitigation measures to deal with this type of risk through policy-making that ensures a strict application of integrated environmental impact assessments and preventive monitoring. Expectantly aiming at avoiding or significantly minimizing dam failure impacts [53].

In the case of Yabous dam, the damage that the flood caused during dam body building and the type of construction materials especially of the core (usually clay), can increase breach width once the flood has dumped on the dam crest. This is expected therefore to increase the flood flow while reduce the flood propagation time. The resistance of materials regardless of the friction angle and coefficient of cohesion can be considered in modeling flood scenario. The low resistance of materials causes its easy removal during the flooding on the ridge, which causes an increase in breach width and lateral slope. Thereby, the rate of eroded materials displaced from the dam body to downstream areas of the dam and river increases as a laden flow [23].

Regardless of breach parameters (slope, width, formation time), the GLMMs indicated that the flood wave flow increased significantly with the increase in wave height $(\mathrm{P}<0.0001)$ and wave width $(\mathrm{P}<0.0001)$. The effect of the flood wave width of the variation 
wave height in the five selected sites was highly significant $(\mathrm{P}<0.0001)$ for all breach parameters (Figure 16). The statistical models showed that the variables of wave flow, both the physical and hydrodynamic, differed significantly among breach adjustment levels $(\mathrm{P}<0.001)$, with values of flood wave variables increasing along a negative-to-positive gradient of adjustment levels $(-50 \%-50 \%)$ of breach slope and width. However, flood wave flow, height and width increased inversely to the increase of breach adjustment levels of breach formation time (Figure 16).

Indeed, the physical and hydrodynamic parameters of the breach slope and the breach width went in the opposite direction compared to the breach formation time (Figure 15). Accordingly, the more the adjustment values of the breach formation time go in the negative direction (i.e. $-25 \%$ and $-50 \%$ ), the higher the physical parameters of breach formation time are. However, the physical and hydrodynamic parameters of the flood wave at the five selected sites decreased for the positive adjustments $(+25 \%$ and $+50 \%$ ) of the breach formation times (Figure 16). As a result, the actual dam-break mechanisms are not well understood. Neither the current physical models nor the empirical models have been able to fully explain the mechanisms and impacts of dam failures [55]. For practical applications, these results contribute to a simple identification of the most prominent breach parameters, therefore, to prioritize resources towards a more precise estimation of their values [56,57]. Otherwise, in earthen dams, several technical factors can influence the general parameters of the breach formation. The first (1) example to mention is the volume of the dam reservoir, the larger the volume is, the more the breach shape increases [58]. The second (2), the type of clay used for the dike core, the more plastic the clay is used (cohesion and friction nail), the more the dam dike will resist against the various floods on the dike crest. Therefore, the resulting breach shape is weak $[59,60]$. The third (3), the thickness of the filters upstream and downstream of the dike core, a wide filter thickness will induce the phenomenon of erosion in the event of a flood spill on the crest. This will systematically give a large breach shape [61]. The fourth (4) is the number of compaction applied on the layers of the dike material during its construction [62]. The fifth (5), the thickness of the layer of the material used for the realization of the dike and in particular the clay material, the lower the thickness of the layer, the more the dike body can resist against the flood spill on the dam crest [63]. The sixth (6), the number of the layers watering the dam material (water content) especially the core material (clay) [62,64]. And the seventh (7) is the protection of upstream and downstream embankments [65]. All these factors have an influence on the general dimensions of the breach (slope, width and height); therefore, the latter can directly influence positively or negatively the physical parameters of the flood wave. In general, the physical parameters of the flood wave are greatly influenced by the width of the breach and the slope of the breach, while it remains essentially insensitive to the time of breach formation $[66,67]$. In return for smaller reservoirs (a larger breach), the formation time has more influence on the outflow than the width of the breach. To this end, a successful proof has been established concerning the approval and significance of these breach parameters on the development of the physical parameters of the flood in the event of a dam failure.

\section{Conclusions}

Dam-break floods cause truly catastrophic and irreparable environmental, social and economic consequences. In order to mitigate flood risks, a prior knowledge on flooding hazard is highly required. The present study demonstrated the effectiveness of HEC-RAS 1D model in simulating the propagation of flood waves downstream the dam in the event of dam-failure. Our findings demonstrated that the maximum flow of Yabous dam-break flood at the level of the breach was $8768 \mathrm{~m}^{3} / \mathrm{s}$, which attenuated gradually along the Yabous river where it recorded a flow of $1579 \mathrm{~m} 3 / \mathrm{s}$ at $3.3 \mathrm{Km}$ from the dam. According to Von Thun and Gillette's method, the dam will run out of water in a very short time ( $\sim 47$ minutes), which stresses on the need of installing a fast and effi- 
cient alarm system. According to the risk map, it turned out that despite the fact that the village of Yabous is predominantly far from flood waves, serious environmental and economic consequences could potentially occur, in particular the damage of two bridges and the agricultural lands destruction.

The interrelationships and contribution rates of the model input parameters are studied by using the sensitivity analysis, performed on three breach parameters i.e. width, slope and training time for four adjustments $(-25 \%,-50 \%,+25 \%$ and $+50 \%)$ over five sites located at an altitudinal gradient downstream the dam. Sensitivity analysis highlighted the significant impact of breach parameters on the dynamic of the flood wave either in the negative or positive direction following the adjustment. The analysis revealed that the influence of breach width and slope on the flood wave are in the same direction, on the one hand. On the other, it is in the opposite direction with respect to the time of breach formation. In addition, it provided useful insights into the uncertainty for the input parameters selection, for any dam design and dam feature of any work. The application of the sensitivity analysis method on dam-break flooding scenario proved the significant association of the physical parameters of the flood wave with the parameters of breach formation.

Author Contributions: Conceptualization, A.G. and H.A.A; methodology, A.G. and H.A.A; software, A.G. and H.C.; validation, A.B., L.B. and H.A.A.; formal analysis, J.B., A.E.K and I.Z.; investigation, A.G. and A.A; resources, A.E.K, J.B. and I.Z.; data curation, A.B., L.B. and H.C.; writing-original draft preparation, A.G, H.A.A, A.B. and L.B,; writing-review and editing, H.A.A., A.E.K., J.B., I.Z. and H.C.; visualization, A.B. and H.C.; supervision, L.B. and H.C.; project administration, A.B.; funding acquisition, H.A.A. All authors have read and agreed to the published version of the manuscript.

Funding: A. E. Krauklis' contribution was funded by the European Regional Development Fund within the Activity 1.1.1.2 "Post-doctoral Research Aid" of the Specific Aid Objective 1.1.1 of the Operational Programme "Growth and Employment" (Nr.1.1.1.2/VIAA/4/20/606).

Data Availability Statement: Not applicable.

Acknowledgments: Many thanks are addressed to the DGRSDT (Directorate General of Scientific Research in Algeria) and the MESRS (Ministry of Higher Education and Scientific Research of Algeria) for their support.

Conflicts of Interest: The authors declare no conflict of interest.

\section{References}

1. Derdous, O.; Djemili, L.; Bouchehed, H.; Tachi, S.E. A GIS based approach for the prediction of the dam break flood hazard - A case study of Zardezas reservoir - Skikda, Algeria. Journal of Water and Land Development 2015, 27, 15-20. https://doi.org/10.1515/jwld-2015-0020.

2. Boussekine, M.; Djemili, L. Modelling approach for gravity dam break analysis. Journal of Water and Land Development 2016, 30, 29-34. https://doi.org/10.1515/jwld-2016-0018.

3. Berghout, A.; Meddi, M. Sediment transport modelling in Wadi Chemora during flood flow events. Journal of Water and Land Development 2016, 31, 23-31. https://doi.org/10.1515/jwld-2016-0033.

4. Wang, B.; Chen, Y.; Wu, C.; Dong, J.; Ma, X.; Song, J. Semi-analytical model for predicting peak discharge of dam-break flood. Hydrological Processes 2016. 30, 3682-3691. https://doi.org/10.1002/hyp.10896.

5. Luino, F.; Tosatti, G.; Bonaria, V. Dam Failures in the 20th Century: Nearly 1,000 Avoidable victims in Italy Alone. Journal of Environmental Science and Engineering 2014, 3, 19-31.

6. Gaagai, A.; Boudoukha, A.; Benaabidate, L. Failure simulation of Babar dam - Algeria and its impact on the valley downstream section. Journal of Water and Land Development 2020, 44, 75-89. https://doi.org/ 10.24425/jwld.2019.127048.

7. Negm, A.; Bouderbala, A.; Chenchouni, H.; Barcelo, D. Water Resources in Algeria- Part I: Assessment of Surface and Groundwater. The Handbook of Environmental Chemistry Series. Springer Nature Switzerland, 2020; http://doi.org/10.1007/978-3-030-57895-4. 
8. Schreider, SY.; Smith, DI.; Jakeman, A.J. Climate Change Impacts on Urban Flooding. Climatic Change 2000, 47, 91-115. https://doi.org/10.1023/A:1005621523177.

9. Nassopoulos, H.; Dumas, P.; Hallegatte, S. Adaptation to an uncertain climate change: cost benefit analysis and robust decision making for dam dimensioning. Climatic Change 2012, 114(3-4), 497-508. https://doi.org/10.1007/s10584-012-0423-7.

10. Arar, A.; Chenchouni, H. How could geomatics promote our knowledge for environmental management in Eastern Algeria. Journal of Environmental Science and Technology 2012, 5(5), 291-305. https://doi.org/10.3923/jest.2012.291.305.

11. ShahiriParsa, A.; Noori, M.; Heydari, M.; Rashidi, M. Floodplain zoning simulation by using HEC-RAS and CCHE2D models in the Sungai Maka river. Air, Soil and Water Research 2016, 9 (9), 55-62. https://doi.org/10.4137/aswr.s36089.

12. Gaagai, A. Etude de l'évolution de la qualité des eaux du barrage de Babar (Sud-Est Algérien) et l'impact de la rupture de la digue sur l'environnement. Doctoral thesis, University of Batna 2, Algeria, 2017. https://doi.org/ 10.13140/RG.2.2.22413.97765.

13. Fluixá-Sanmartín, J.; Morales-Torres, A.; Escuder-Bueno, I.; Paredes-Arquiola, J. Quantification of climate change impact on dam failure risk under hydrological scenarios: a case study from a Spanish dam. Nat. Hazards Earth Syst. Sci 2019, 19, $2117-2139$. https://doi.org/10.5194/nhess-19-2117-2019.

14. Lee, B.S.; You, G.J.Y. An assessment of long-term overtopping risk and optimal termination time of dam under climate change. J. Environ. Manage 2013, 121, 57-71. http:// doi.org/10.1016/j.jenvman.2013.02.

15. Kundzewicz, Z. W.; Kanae, S.; Seneviratne, S. I.; Handmer, J. W.; Nicholls, N.; Peduzzi, P.; Mechler, R.; Bouwer, L. M.; Arnell, N.; Mach, K. J.; Muir-Wood, R.; Brakenridge, R.; Kron, W.; Benito, G.; Honda, Y.; Takahashi, K.; Sherstyukov, B.. Flood risk and climate change: Global and regional perspectives. Hydrological Sciences Journal/Journal des Sciences, Hydrologiques 2014, 59(1), 1 28. https://doi.org/10.1080/02626667.2013.857411.

16. Delenne, C.; Cappelaere, B.; Guinot, V. Uncertainty analysis of river flooding and dam failure risks using local sensitivity computations, Reliab. Eng. Syst. Safety 2012, 107, 171-183, https://doi.org/10.1016/j.ress.2012.04.007.

17. Guo, X.; Dias, D.; Pan, Q. Probabilistic stability analysis of an embankment dam considering soil spatial variability. Computers and Geotechnics 2019, 113, 93-103. https://doi.org/10.1016/j.compgeo.2019.103093.

18. Singh, V.P.; Scarlatos, P.D. Analysis of Gradual Earth-Dam Failure. Journal of Hydraulic Engineering 1988, 114, 21-42. https://doi.org/10.1061/(asce)hy.1943-7900.0000498.

19. Israa, D.A.; Qassem, H. J.; Jasim, M.A. Sensitivity Analysis for Dam Breach Parameters Using Different Approaches for Hamrin Dam. Diyala Journal of Engineering Sciences 2021, 14 (4), 90-97. DOI: 10.24237/djes.2021.14408.

20. Pektas, A.O.; Erdik, T. Peak discharge prediction due to embankment dam break by using sensitivity analysis based ANN. KSCE Journal of Civil Engineering 2014, 18, 1868-1876. https://doi.org/10.1007/s12205-014-0047-8.

21. Xanthopoulos, T.h.; Koutitas, C.H. Numerical simulation of two dimensional flood wave propagation due to dam failure. Journal of Hydraulic Research 1976, 14(4), 321-331. https://doi.org/10.1080/00221687609499664.

22. Hervouet, J.M. A high-resolution 2-D dam-break model using parallelization. Hydrological processes 2000, 14(13), $2211-2230$. https://doi.org/10.1002/1099-1085(200009)14:13<2211::aid-hyp24>3.0.co;2-8.

23. Tony, L.; Wahl, T.L. Uncertainty of predictions of embankment dam breach parameters. Journal of Hydraulic Engineering 2004, 130 (5), 389. https://doi.org/10.1061/(asce)0733-9429.

24. Sadrolashrafi, S.S.; Thamer, A.M.; Ahmad, R.B.M.; MajidK, K.; Amir, S. Integrated modeling for flood hazard mapping using watershed modeling system. American Journal of Engineering and Applied Sciences 2008, 1(2), 149-156. https://doi.org/10.3844/ajea ssp.2008.149.156.

25. Mao, J.; Wang, S.; Ni, J.; Xi, C.; Wang, J. Management System for Dam-Break Hazard Mapping in a Complex Basin Environment. ISPRS Int. J. Geo-Inf 2017, 6, 162. https://doi.org/10.3390 /ijgi6060162.

26. Gee, M.; brunner, G. Dam Break Flood Routing Using HEC-RAS and NWS-FLDWAV Conference. World Water and Environmental Resources Congress 2005. https://doi.org/10.1061/40792(173)401.

27. Albu, L.M.; Enea, A.; Iosub, M.; Breabăn, L.G. Dam breach size comparison for flood simulations. A HEC-RAS based, gis approach for Drăcșani Lake, Sitna River, Romania. Water 2020, 12(4), 1090. https://doi.org/10.3390/w12041090.

28. Hafnaoui, M.A.; Madi, M.; Hachemi, A.; Farhi, Y. El Bayadh city against flash floods: case study. Urban Water Journal 2020, 17(5), 390-395. https://doi.org/10.1080/1573062x.2020.1714671.

29. Tamm, O.;Tamm, T.. Verification of a robust method for sizing and siting the small hydropower run-of-river plant potential by using GIS. Renewable Energy 2020, 155, 153-159. https://doi.org/10.1016/j.renene.2020.03.062.

30. Oudni, A.; Dinar, H. Caractérisation géologique et géotechnique de la cuvette du barrage Tagharist. Yabous, Wilaya de Khenchela. Master dissertation, University of Oum El Bouaghi, Algeria 2016.

31. Chenchouni, H. Statuts de protection et de conservation des oiseaux recensés dans les Aurès et ses alentours (nord-est algérien). Proceedings of the international Conference "SIBFA", Univ Ouargla, 2010 ; pp. 56-75.

32. USACE. HEC-RAS Version 4.1 [Hydraulic reference manual]. Davis, CA. Hydrologic Engineering Center, U.S. Army Corps of Engineers 2008. https://www.hec.usace.army.mil/software/HEC-RAS/documentation/hec ras_4.1_reference_manual.pdf.

33. Hu, H.H.; Walton, R. Advanced guidance on use of steady HEC-RAS. World Environmental and Water Resources Congress 2008, 4 , 12-16. https://doi.org/10.1061/40976(316)201.

34. Haltas, I.; Tayfur, G.; Elci, S. Two-dimensional numerical modeling of flood wave propagation in an urban area due to Urkmez dam-break, Izmir, Turkey. Natural Hazards 2016, 81, 2103-2119. https://doi.org/10.1007/s11069-016-2175-6.

35. Chow, V.T. Open-channel Hydraulics. McGraw-Hill, New York 1959.

36. Sammen, S.S.; Mohamed, T.A.; Ghazali, A.H.; Sidek, L.M.; El-Shafie, A. An evaluation of existent methods for estimation of embankment dam breach parameters. Natural Hazards 2017, 87, 545-566. https://doi.org/10.1007/s11069-017-2764-z. 
37. MacDonald, T.C.; Langridge-Monopolis, J. Breaching characteristics of dam failures. Journal Hydraulic Engineering 1984, 110, 567-586. https:// https://doi.org/10.1061/(ASCE)0733-9429(1984)110:5(567).

38. Von Thun, J.L.; Gillette, D.R. Guidance on Breach Parameters. Unpublished internal document, U. S. Bureau of Reclamation, Denver, Colorado, 1990.

39. Froehlich, D.C. Embankment dam breach parameters and their uncertainties. Journal Hydraulic Engineering 2008, 134(12), 1708-1721. https://doi.org/10.1061/(asce)0733-9429.

40. Froehlich, D.C. Peak Outflow from Breached Embankment Dam. Journal of Water Resources in Planning and Management 1995, 121, 90-97. https://doi.org/10.1061/(ASCE)0733-9496(1995)121:1(90).

41. Core Team, R. R: A language and environment for statistical computing. R Foundation for Statistical Computing, Vienna, Austria 2020. URL: https://www.R-project.org.

42. Prettenthaler, F.; Amrusch, P.; Habsburg-Lothringen, C. Estimation of an absolute flood damage curve based on an Austrian case study under a dam breach Scenario. Nat. Hazards Earth Syst. Sci 2010, 10, 881-894. https://doi.org/10.5194/nhess-10-881-2010.

43. McMahon, G.F. Developing dam-break flood zone ordinance. Journal of the Water Resources Planning and Management Division 1981, 1072, 461-476. https://doi.org/10.1061/(ASCE)0733-9429(2008)134:12(1708).

44. Wahl, T.L. Uncertainty of predictions of embankment dam breach parameters. Journal of Hydraulic Engineering 2004, 130, 389-397. https://doi.org/10.1061/(asce)0733-9429.

45. Shahrim, M.F.; Ros F.C. Estimation of breach outflow hydrograph using selected regression breach equations. 2 nd International Conference on Civil \& Environmental Engineering 2020, 476, 012129. https://doi.org/10.1088/1755-1315/476/1/012129.

46. Chanson, H. Application of the method of characteristics to the dam break wave problem. J. Hydraul. Res 2009, 47(1), 41-49. https://doi.org/10.3826/jhr.2009.2865.

47. Wang, B.; Chen ,Y.; Wu, Ch.; Peng, Y.; Ma, X.; Song, J. Analytical solution of dam-break flood wave propagation in a dry sloped channel with an irregular-shaped cross-section. Journal of Hydro-environment Research 2017, 14, 93-104. https://doi.org/10.1016/j.jher.2016.11.003.

48. Gallegos, H.A.; Schubert, J.E.; Sanders, B.F. Structural damage prediction in a high-velocity urban dam-break flood: Field-scale assessment of predictive skill. Journal of Engineering Mechanics 2012, 138(10), 1249-1262. https://doi.org/10.1061/(asce)em.1943-7889.0000427.

49. Gaagai, A.; Boudoukha, A.; Boumezbeur, A.; Benaabidate, L. Hydrochemical characterization of surface water in the Babar watershed (Algeria) using environmetric techniques and time series analysis. International Journal of River Basin Management 2017, 15, 361-372. https://doi.org/10.1080/15715124.2017.1299157.

50. Tamm, T.; Noges, T.; Jarvet, A.; Bouraoui, F. Contributions of DOC from Surface and Groundflow into Lake Vortsjarv (Estonia). Hydrobiologia 2008, 599 (1), 213-220. JRC50030. https://doi.org/10.1007/s10750-007-9189-8.

51. Aouissi, H.A.; Ababsa, M.; Gaagai, A.; Bouslama, Z.; Farhi, Y.; Chenchouni, H. Does melanin-based plumage coloration reflect health status of free-living birds in urban environments? Avian Res 2021, 12 (1), 45. https://doi.org/10.1186/s40657-021-00280-7.

52. Aouissi, H.A.; Petrişor, A.I.; Ababsa, M.; Boştenaru-Dan, M.; Tourki, M.; Bouslama, Z. Influence of Land Use on Avian Diversity in North African Urban Environments. Land 2021, 10(4), 434. https://doi.org/10.3390/land10040434.

53. Fernandes, G.W.; Goulart, F.F.; Ranieri, B.D.; Coelho, M.S.; Dales, K.; Boesche, N.; Bustamante, M.; Carvalho, F.A.; Carvalho, D.C.; Dirzo, R.; Fernandes, S.; Galetti, P.M.; Millan, V.E.G.; Mielke, C.; Ramirez, J.L.; Neves, A.; Rogass, C.; Ribeiro, S.P.; Scariot, A.; Soares-Filho, B. Ecological and socio-economic impacts of the dam breach in Mariana, Brazil, Natureza E Conservação 2016, 14(2), 35-45. https://doi.org/10.1016/j.ncon.2016.10.003.

54. Hatje, V.; Pedreira, R.M.; de Rezende, C.E.; Schettini, C.A.F.; de Souza, G.C.; Marin, D.C.; Hackspacher, P.C. The environmental impacts of one of the largest tailing dam failures worldwide. Scientific Reports 2017, 7, 10706. https://doi.org/10.1038/s41598-017-11143-x.

55. Xiong, Y.A. Dam Break Analysis Using HEC-RAS. Journal of Water Resource and Protection 2011, 3, 370-379. https://doi.org/10.4236/jwarp.2011.36047.

56. Dewals, B.; Erpicum, S.; Detrembleur, S.; Archambeau, P.; Pirotton, M. Failure of dams arranged in series or in complex. Natural Hazards 2011, 56, 917-939. https://doi.org/10.1007/s 11069-010-9600-z.

57. Bencedira, S.; Bechiri, O. Degradation of fuchsine acid using the HP2W15Mo3Co2.5O62, 20H2O/H2O2 system: effect of organic and inorganic additives. Euro-Mediterr J Environ Integr 2021, 6(2), 60. https://doi.org/10.1007/s41207-021-00260-9.

58. Clague, J.J.; Evans, S.G. A Review of catastrophic drainage of moraine-dammed lakes in British Columbia. Quaternary Science Reviews 2000, 19, 1763-1783. https://doi.org/10.1016/S0277-3791(00)00090-1.

59. Al-Riffai, M.; Nistor, I. Impact and analysis of geotechnical processes on earth fill dam breaching. Natural Hazards 2010, 55, 15-27. https://doi.org/10.1007/s11069-010-9586-6.

60. Al-Riffai, M.; Nistor, I.; Vanapalli, S.K.; Orendorff, B. Overtopping of earth embankments: sensitivity analysis on dam breach parameters using two numerical models. Proceedings of the 60th Canadian Geotechnical Conference, Ottawa, Canada, 2007; pp. $1213-1220$.

61. Minguez, R.; Delgado, F.; Escuder, I.; de Membrillera, M.G. Reliability assessment of granular filters in embankment dams. International journal for numerical and analytical methods in geomechanics 2006, 30, 1019-1037. https://doi.org/10.1002/nag.511.

62. Zhang, L.; Gelet, R.; Marot, D.; Smith, M.; Konrad, J.M. A method to assess the suffusion susceptibility of low permeability core soils in compacted dams based on construction data. European Journal of Environmental and Civil Engineering 2018, 23(5), 626-644. https://doi.org/10.1080/19648189.2018.1474386. 
63. Zhong, Q.M.; Chen, I.S.S.; Mei, I.S.A.; Cao, I.W. Numerical simulation of landslide dam breaching due to overtopping. Landslides 2017, 8(3), 321-332. https://doi.org/10.1007/s10346-017-0935-3.

64. Gaagai, A.; Aouissi, H.A.; Maalam, S.E.; Ababsa, M. Contribution of statistical analysis methods to assessment of the physicochemical quality of the dam. Op Acc J Bio Sci Res 2020, 4(5). https://doi.org/10.46718/JBGSR.2020.04.000109.

65. Neilsen, M.L. Global sensitivity analysis of dam erosion models, in Proceedings of the 10th International Conference on Scientific Computing, 2013; Paper No. CSC-3502.

66. Singh, K.P.; Snorrason, A. Sensitivity of outflow peaks and flood stages to the selection of dam breach parameters and simulation models. Journal of hydrology 1984, 68, 295-310. https://doi.org/10.1016/0022-1694(84)90217-8.

67. Dewals, B.J.; Archambeau, P.; Erpicum, S.; Detrembleur, S.; Pirotton, M. Sensitivity analysis of the peak outflow induced by the breaching of embankment dams. In: Rutschmann P. (Ed) Proceedings of 14th German Dam symposium \& 7 th ICOLD European club dam symposium. Technische Universität München, 2007; pp 86-92. 